Article

\title{
Importance of Social Media in the Image Formation of Tourist Destinations from the Stakeholders' Perspective
}

\author{
Carlos de las Heras-Pedrosa ${ }^{1}\left(\mathbb{0}\right.$, Elena Millan-Celis ${ }^{1} \oplus$, Patricia P. Iglesias-Sánchez ${ }^{2} \mathbb{D}$ and \\ Carmen Jambrino-Maldonado $2, *$ (D) \\ 1 Department of Advertising and Public Relations, Universidad de Málaga, 29071 Málaga, Spain; \\ cheras@uma.es (C.d.1.H.-P.); elenamillan@uma.es (E.M.-C.) \\ 2 Department of Economics and Business Administration, Universidad de Málaga, 29071 Málaga, Spain; \\ patricia.iglesias@uma.es \\ * Correspondence: mcjambrino@uma.es
}

Received: 6 April 2020; Accepted: 14 May 2020; Published: 17 May 2020

\begin{abstract}
This research aimed to provide a more informed and systematic basis on which to develop the positioning strategy in social media due to the interactive capacity and influence that social media has in the success of tourist destinations. In particular, we investigated the role of stakeholders. We carried out an exploratory study using a mixed method which included interviews and an analysis of the activity conducted on the official social media accounts (Facebook, Twitter, and Instagram) of the Spanish regions of Andalusia, Catalonia, and Valencia. The findings provide insight into how tourist destinations promote their image through the use of social media. Social media was found to be a strategic platform for enhancing brand image and achieving tourist engagement. Additionally, the role of stakeholders in supporting and facilitating the image destination strategy is worth highlighting. This study shows that the results achieved by social media can be improved by identifying all stakeholders and defining a content generation strategy by integrating and adding value.
\end{abstract}

Keywords: tourist destinations; social media; destination image; stakeholders

\section{Introduction}

Tourism is an economic activity that represents an important revenue source globally and is the third most important activity in the exportation category. According to the Spanish Instituto Nacional de Estadística (INE) [1], Spain banked 87,856 million EUR in tourist revenue, an increase of 3.3\% compared with 2017.

The economic significance of tourism, along with the spread of globalization, given the constant demand for information in this sector, makes the promotion of tourist destinations fundamental. Yet, the speed of accessing information and the fast updating of technologies increasingly alter the behaviours of users and directly affect the business models of tourist destinations.

According to INE [1] data, currently, over $80 \%$ of users search for information on products and services prior to making a purchase [1]. This is the case when it comes to travel. Thus, the process of planning the trip is increasingly being more dominated by online tools and travellers' opinions.

The tourist industry is one of the sectors where the use of new communication technologies has had the greatest impact [2,3]. Therefore, global tourist destinations are competing to attract tourists. The main aspects involved in attracting travellers and enhancing the visibility of cities are having an online presence and successfully managing social media. However, it is not enough just to understand how tourist destinations use social media to promote themselves. It is necessary to know how stakeholders contribute to the promotion of tourist destinations and brand image. 
According to the Annual Social Media Report [4], eight out of every 10 users consider social media to be a good setting to interact with brands. Due to the economic crisis and the rise of social media, destinations have increased their online communication investment to the detriment of traditional methods. This is the reason why this study solely focuses on the online dimension of promoting tourist destinations.

It is well known that the literature about destination image [5-14] and social media in tourism [15-17] is very extensive. Especially, there has been an increase in studies in recent years, as both concepts have been adopted together [18]. However, to date, there has been little research focused on the tourist destination brand image development concept from the stakeholder point of view. Many studies have been based on how destinations use social media to promote themselves and boost their image [19], the image perceived by tourists as a consequence of social media strategies carried out [20], or how tourists become co-creators of the image of a destination though social media platforms [21-23]. However, there are other stakeholders that have been unnoticed or simply not studied through a holistic and integrated manner. This is the reason why our work uses the triple helix model to address this issue as a central axis.

The main objective of this research work is to provide insight into how tourist destinations promote their image through the use of social media and how they communicate with stakeholders. We also consider what type of content is shared to the public.

This study is divided into six sections. After this introduction, a review of the previous literature focused on social media used by tourism destinations is made and some research questions are asked. Secondly, an approach based on the stakeholder perspective using a mixed method is introduced in the methodology section. Specifically, qualitative content analysis and interviews are combined with quantitative data obtained using online tools. The fourth section deals with the empirical work and shows that social media can be used as strategic platforms to enhance brand image and generate value. The fifth part contains the main contribution. It should be pointed out that the role of stakeholders supports destinations in their image strategies. In addition, all content generated by users (UGC) involves tourists who help to form the image of a destination through social media. Finally, some limitations of the research and tips about the use of social media by tourism destinations are proposed.

\section{Literature Review}

\subsection{Social Media in the Development of Destination Image}

The World Tourism Organization [24] defines a tourist destination, from a merely geographical perspective, as follows: "a place where demand travel to consume the tourist product" (p. 20). Although tourist destinations have been widely explored in different studies, it is recognized that, as a multiactivity grouping, they compete based on a spatial cooperation strategy to offer integrated tourist products that are assessed and judged by potential tourists; this is significantly broader than the previous definition [25]. Others, such as Murphy, et al. [26], consider tourist destination to be products but offer an unparalleled experience to tourists. Gunn and Var [27] uses the term "experience" when attempting to understand what a tourist destination is. This is the result of a process where tourists use multiple tourist services during their visit.

Therefore, a tourist destination should not be based simply on a geographical definition [14,24] or on an agglomeration of services or products [26]. Tourist destinations contain the six As: attractions, accessibility, amenities, available packages, activities, and ancillary services [28].

From a tourism stakeholder approach, a destination is defined as an open system of multiple interdependent stakeholders, among whom different interactions occur and whose decisions and actions have different levels of influence and impact on others [29].

Destination image has acquired a special key role in diverse research fields such as anthropology, sociology, geography, and marketing due to the impact that it has on human behavior [30]. 
Destination image is a concept that includes the sum of all the beliefs, ideas, and impressions that a tourist has about a destination [14,31]. Previous studies argued that it plays a crucial role in the configuration of tourist preferences and opinions regarding visiting tourist destinations [32]. Destination image has been used as a strategy by destination marketers to differentiate their brand from other competitors [33,34]. Considering the intangible nature of destination experience, Pike [35] stated that an image is one way to compete with other destinations.

At this point, it should be highlighted that destination image is a rather multidimensional and complex concept that involves both tourist supply and demand forces $[13,36,37]$. The characteristics of the cultural and natural heritage of a destination are the fundamental attributes that define its identity and, therefore, contribute to the formation of its image as a tourist destination [38].

Iconic elements and attributes can be considered tools for the economic and sustainable development of a tourism destination [39]. These elements of authenticity and mental insight build the image of iconic attractions [40-42] and serve as universally recognized symbols or represent their locations, culture, and natural heritage, promoting a positive image between visitors and local residents.

Destinations that include iconic elements in their promotions such as culture, heritage, gastronomy, or buildings and attractions provide a memorable image that potential visitors will associate with them [43]. The use of tourist icons is common in the positioning of the destination and are the result of a long-term communication and marketing process that involves stakeholders [44].

The classification of a place as a tourism destination has been widely identified as being a result of characteristics and emotional evaluations associated with it. Gallarza et al [30] stated that destination image is complex, multiple, relativistic, and dynamic. Boo, Busser, and Baloglu [45] demonstrated the brand of a destination with a model oriented toward the promotion and communication of all positive values that a destination can offer to tourists. They found that the more attractive the destination image is, the more likely a destination will be chosen [46]. These authors stated that an effective communication strategy will project a strong image online as well as facilitate the differentiation of a destination from its competitors.

One of the research subjects in the area of tourist destinations is the capacity of Destination Marketing Organisations (DMO) to develop or coordinate the destination brand [47,48].

In her critical dissertation, L'Etang [49] summarized the relationship between tourism and DMO in three points: First, the impact of tourism in terms of the social and economic development of the destination and how DMO must contribute to the sustainable development of a destination; second, the vulnerability of tourism in the face of crises because of its intangibility. The tourism sector is very sensitive to actions, crisis or events. A clear example is the catastrophic effect of terrorist attacks carried out in tourism destinations [50]. Third, L'Etang [49] placed great emphasis on the promotion of a destination by means of a mega-event or iconic attributes.

The perceived destination image has been said to be composed of three components over the last few decades: affective, cognitive, and behavioral [14,36,51]. Once an overall tourist destination brand image is formed, a tourist is able to make a destination vacation choice; the brand image directly affects tourists' intentions to visit a destination $[52,53]$.

Value generation can be provided by social media interactivity, therefore enhancing the destination image in tourists' minds [17]. However, DMOs should be consistent in their use of social media to create a positive image among all stakeholders.

The Internet has become an essential tool for users in the decision-making process, allowing them to search for information on products and services, to compare and assess the alternatives, and finally, to make bookings on the spot [54]. Likewise, "Web 2.0" adds a wide range of electronic applications (social media sites, online recommendation sites, blogs, and video and photo sharing platforms) that enable interactions between users and between users and companies [55].

Therefore, something that is quite clear is that using social media means having an element that enables interactivity. As Roca [56] explained, "It is not enough to be present and argue, 
starting conversations and listening is also needed, not merely [telling the users] things because what they want is to be allowed to be involved in opinion forming" (p. 70). Based on the above, the following research questions were formulated:

RQ1. What kind of content is shared by the official profiles of destinations selected in social media?

RQ2. How is social media used to promote tourist destinations?

RQ3. How does social media management affect the official profiles or accounts analyzed in terms of engagement?

The appearance of Web 2.0 has allowed tourists to have access to and control powerful mouth-to-mouth electronic tools and has given them the opportunity to express personal opinions to an audience of millions of possible other tourists [15,57].

DMOs can use social media as a place where they can obtain information about their needs as consumers and establish the relationship between the brand and consumers at an insignificant cost $[58,59]$. It can even be used to promote their brand image or create the idea that their destination is the next destination that a tourist needs to visit [7,60] In line with Ren, Pritchard and Morgan [61], tourism destination brand image development helps to improve marketing effectiveness and attract visitors [61-63]

Social media is also recognised as a communication and public relations tool [64] and, as such, it allows effective communication of destination brands and aids in the development of a relationship with users [65]. Furthermore, many studies reinforce the idea that conversations between users and tourist accounts in social media help to create territories and allow the latter to identify with the users [66-68]. This shows that social media has positive effects on the relationship between a user and a brand, which leads to greater credibility and loyalty [68]. In recent studies [16,22], the impact of destination branding has been highlighted. Destination image is a factor that influences tourist destinations in a positive way [8-10]. As a consequence, social media should be considered as an active component in the development of destination image [69,70].

Social media is considered a useful tool for DMO even though its use is often limited or not fully exploited [18,71]. A greater and better effort may be needed to bring people to the brand community based on social media and to retain them as loyal consumers [72]. This leads us to propose the following hypotheses:

H1. Tourist destination promotes its image on social media through its icons and main attributes.

H2. Social media supports the management of destination image, generating useful content for tourists.

The communication department takes this concept in account. The Andalusian Tourism Promotion Plan of Junta de Andalucía [73] acknowledges that "social media now plays a key role in the everyday life of a great part of the population, both in Spain and abroad. All economic sectors consider social media to be a fundamental factor to promote their business and that is no less true for tourist activity" (p. 75).

\subsection{User-Generated Content}

The impact of the content generated by users is growing rapidly and its role has become increasingly more fundamental for the success of a destination [12,74]. This was partly explained by De Bruyn and Lilien [75] who reinforced the idea that this type of content is under high demand and creates expectations about a tourist destination [75,76]. User-Generated Content (UGC), especially regarding tourist experiences, is transmitted through social media [6], allowing tourists, particularly younger people, to be involved in forming the image of any travel destination $[16,71,77]$.

UGC in social media can be highly useful for understanding the needs and wants of tourists and specific suggestions for the products/services they consume [78]. Assessing individuals' motivations allows their choices, needs, and expectations to be understood, and this has been widely explored in tourism $[79,80]$. 
Blogs, social media, and videos are some of the elements that allow the users themselves to become influencers [81]. According to Standing et al. [82], travel 2.0 has been revolutionized because there is a large amount of UGC in the form of travel blogs and online travel reviews (OTR) that allows other users to experience the events that travellers share first-hand through social media platforms during their stay at a destination.

Theoretical frameworks allow us to accept that all content created by users takes part in the processes of building and promoting destination image [12,23,55,77,83,84].

According to Marine-Roig and Clavé [85], tourism data are considered to be a good source of information for national tourism organizations (NTOs) and other policymakers, destination marketing organizations (DMOs), and stakeholders, because they consist of opinions that are freely expressed by tourists who have visited the destination (p. 203).

At this point, another research question emerges:

RQ4. User-generated content is the key to

RQ4.1 Gaining more interactions

RQ4.2 Understanding stakeholders' interests and expectations

\subsection{Role of Tourism Stakeholders}

Definitions of the term range from those that only understand stakeholders as actors of organizations $[86,87]$ to other authors who include any actor [88].

One of the first authors to offer a broad stakeholder vision was Freeman [89], who stated that a stakeholder is "any group or individual who can affect, or is affected by, the achievement of a corporation's purpose" (p. vi). Furthermore, there are those who differentiate stakeholders into strategic and moral stakeholders [90]. A reviewing about classifications of other authors has been carried out (Table 1).

Table 1. Types of stakeholders identified by authors. Source: Own elaboration.

\begin{tabular}{cc}
\hline Authors & Stakeholders Identified \\
\hline Timur and Getz [91]; Sun [92] & $\begin{array}{c}\text { Government bodies, tourist and hospitality firms, tourists (the } \\
\text { key pieces to the tourism industry) and residents }\end{array}$ \\
\hline García, Gómez and Molina [93] & $\begin{array}{c}\text { Local residents of the destination, employees, investors, tourists, } \\
\text { and travel intermediaries like airlines, travel agencies, and so on }\end{array}$ \\
Sheehan, Ritchie and Hudson [94] & $\begin{array}{c}\text { Three pertinent destination stakeholders-the city or } \\
\text { government, hotels, and the destination marketing } \\
\text { organisations (DMOs) }\end{array}$ \\
\hline Bitsani and Kavoura [95] & $\begin{array}{c}\text { Tourism hosts a community including locals who are also } \\
\text { tourism entrepreneurs }\end{array}$ \\
\hline Simpson [96] & $\begin{array}{c}\text { Government, private sector, national government organisations } \\
\text { (NGOs) and communities }\end{array}$ \\
\hline Clarkson [97]; Dodds and Ko, [98] & Multiple primary and secondary tourism stakeholders \\
\hline
\end{tabular}

Six large groups of stakeholders common to all were identified (Table 2): the public sector, private sector (tourism companies and other local businesses), tourists (international and domestic), civil society [29,99], and opinion leaders and universities [100]. 
Table 2. Examples of stakeholders from tourism destinations observed in the study. Source: Own elaboration.

\begin{tabular}{|c|c|}
\hline Primary Stakeholders & Stakeholders on Tourism Destinations \\
\hline Public sector (DMOs) & $\begin{array}{l}\text { Public institutions and government agencies that } \\
\text { carry out strategies to promote tourist regions }\end{array}$ \\
\hline Opinion leaders & $\begin{array}{l}\text { Influencers, politicians, businessmen, investors, } \\
\text { directors of media }\end{array}$ \\
\hline Civil society & Citizens from destinations \\
\hline University & $\begin{array}{c}\text { Academics and experts in promoting tourism } \\
\text { destinations in social media }\end{array}$ \\
\hline Tourists & $\begin{array}{l}\text { National and foreign tourists with social } \\
\text { media accounts }\end{array}$ \\
\hline Private sector & Companies and entrepreneurs in the tourism sector \\
\hline
\end{tabular}

This is, in part, essential, since, as stated in the Stakeholder Theory (1984) [89], the knowledge of the different agents that interact in the participatory procedures of tourist destinations is necessary for the understanding of their interests and expectations, as well as the interdependencies and interactions that occur between them.

In tourism, considering the role of stakeholders in communication management is important to achieve a positive image of the destination $[49,101,102]$. Thus, the following research question is proposed:

RQ5. How do stakeholders participate in the promotion of a tourist destination?

Sautter and Leisen [103] claimed that, in destination management, all stakeholders should be considered and this will lead to significant returns of tourism in the long term [104,105]. Stakeholder management of investor, tourist, and resident attractions first requires the identification of expectations and their interests [106].

As Saxton and Waters [107] noted in their recent work, the increasingly wide adoption of social media offers the opportunity to observe stakeholders' online engagement corresponding to organizational communication. Capriotti [108] stated that the use of indicators is key when analyzing and auditing the corporate image perceived by the different stakeholders as well as the quality of the interactions and the real effects of the corporate identity.

Gartner [34] made important contributions by proposing destination image as a cyclical process in which stakeholders play a key role [109]. Chon [110] suggested that it depends particularly on tourists' cognitive perception, while other authors [14] considered that both operate together to produce a composite destination image. The current trend in the tourist market is that tourists have become creators of original content for tourist destinations and, therefore, have become very powerful and influential stakeholders [14,111,112].

Marketing efforts should be tailored to the needs of each stakeholder (tourists, residents, tourism sector and government); thus, diluting the image of each of the various stakeholders is essential for the success of destination promotion $[11,113]$.

\section{Methods}

All information was gathered using a qualitative approach through interviews combined with a quantitative approach with the data obtained through online tools and content analysis. The goal of these mixed methods was to provide useful practical recommendations for all Spanish tourist destinations on the use of social media. Mixed methods are a research design (or methodology) in which a researcher collects, analyses, and mixes (integrates or connects) quantitative and qualitative data in a single study or a multiphase program of inquiry [114]. 
Bryman [115] also suggested several practical reasons to consider mixed methods such as attractivity to stakeholders, improving the chance of getting funding, etc. In addition, Cai [116] highlighted the fact that the use of mixed methods could be a way to make both researchers and research distinctive in this research field.

In spite of the fact that a mixed methods approach was used, the qualitative part played the main role in this research. Its application is recommended for the studied phenomenon $[9,21]$. Quantitative analysis was chosen to classify and measure the main social media metric, engagement [60], while the qualitative method was used to gain depth in issues that could be lost during statistical processing [18].

This study began with a content analysis, an ideal tool for quantitative research, in order to use certain types of data to formulate reproducible interferences in other contexts [117]. Its usefulness for compiling, processing, and assessing large amounts of information [118] and its frequent use when describing the components of the media messages [119], made this the most appropriate investigation method for our work. We also took the model of de las Heras-Pedrosa et al. [120] into account, as this is a useful way to identify stakeholders in tourist destinations and to determine the research techniques to be applied in each case. The analysis process was partly based on the interactive model of Miles and Huberman [121], using the phases of data collection, data reduction, data display, and conclusions. These phases are shown in Figure 1.

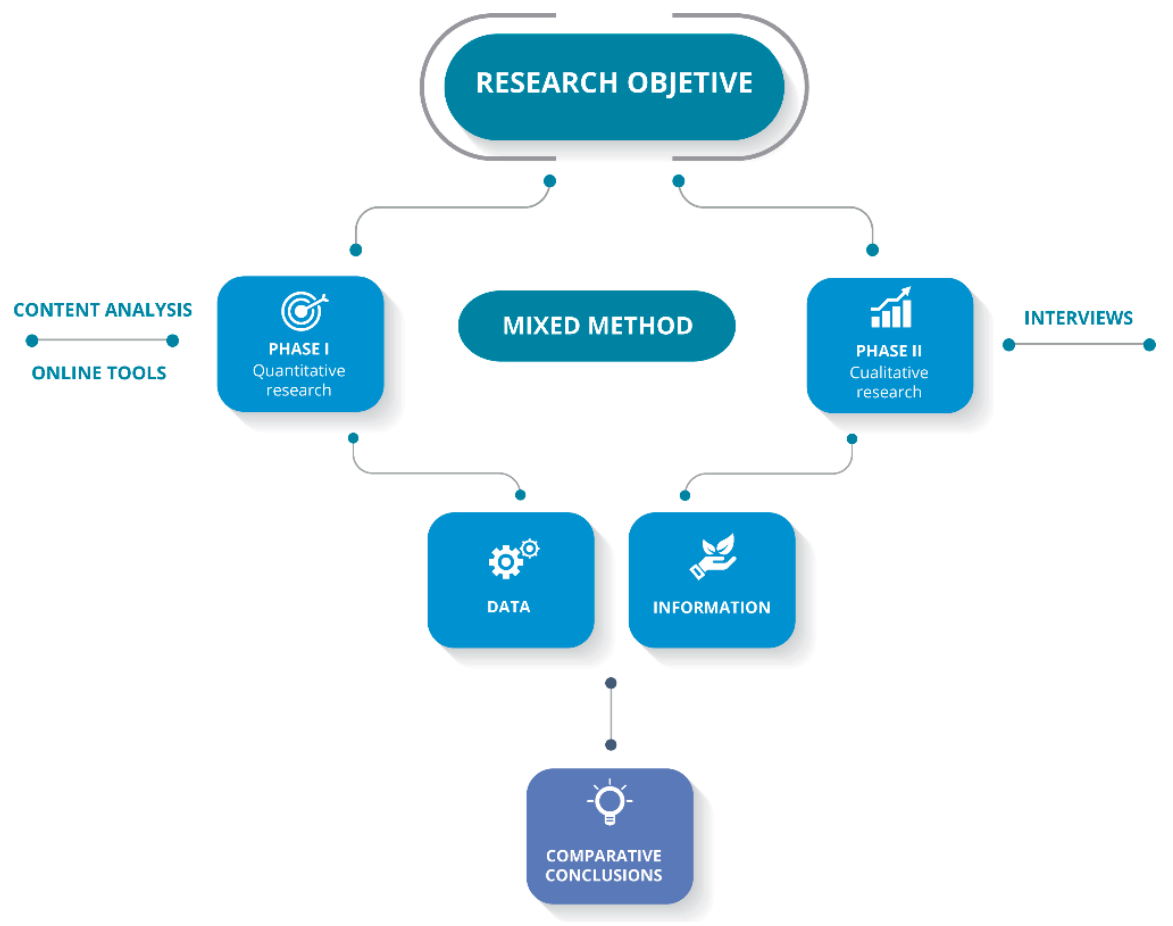

Figure 1. Research phases followed. Source: Own elaboration.

Social media from the official tourism websites of Andalusia, Catalonia, and Valencia were analysed. These destinations were selected as they are the main Spanish mainland tourist destinations according to data from INE [1], as shown in Figure 2. The cases selected may be representative of national tourist, as they include data taken from a large-scale study. The empirical evidence showed that there are extensive relationships and logic among the constructs [122]. Analysing this content means the public sector is taking government-determined actions further with tourism policies that represent government initiatives to develop tourism [123]. 


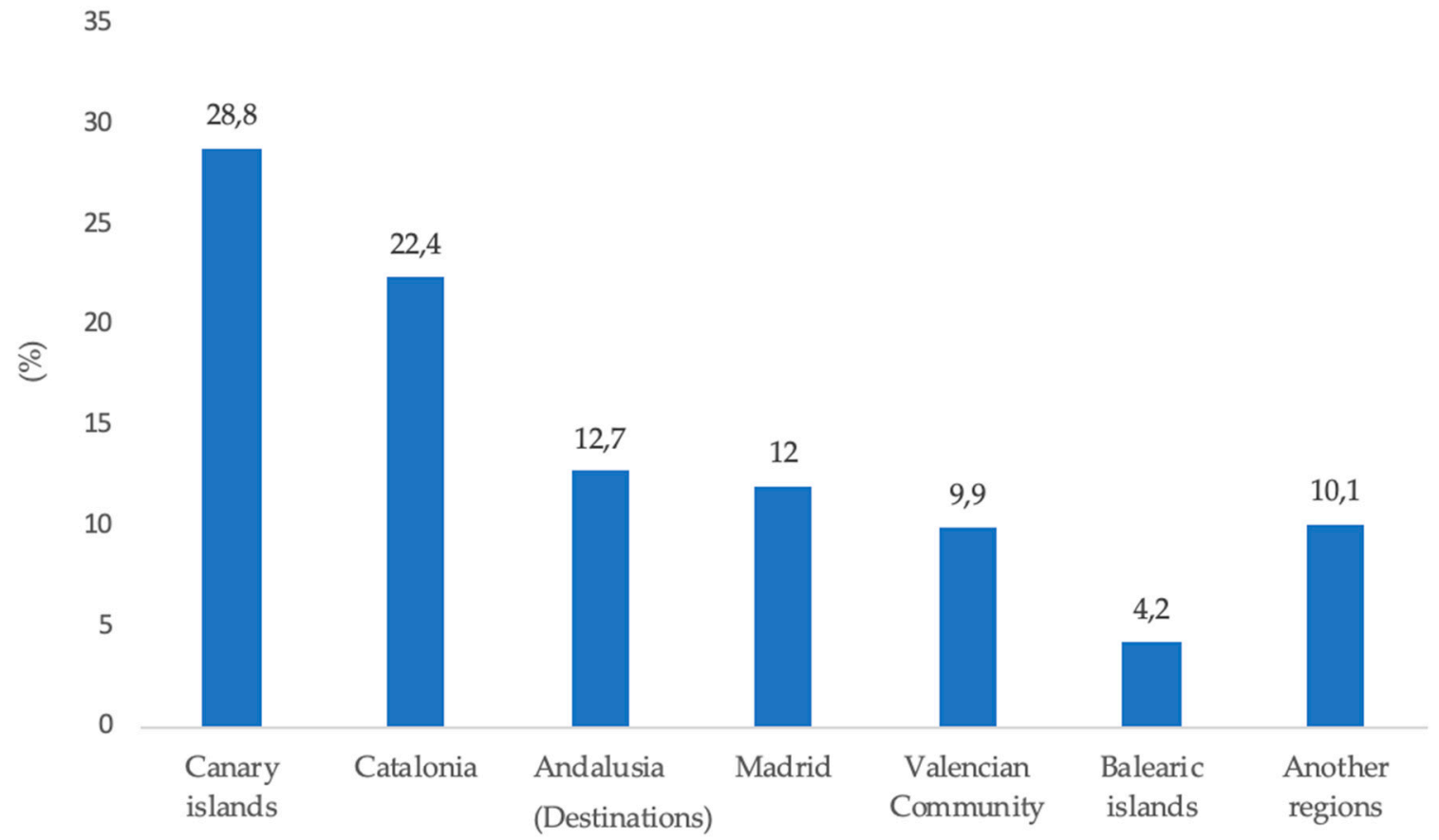

Figure 2. Percentage of tourists who have visited Spanish destinations. Source: Own elaboration based on INE [1].

The social media selected for the analysis were the Facebook, Twitter, and Instagram accounts of the aforementioned destinations, because they are the most frequently used according to the Annual Social Media Report for Spain [4].

Destinations were specifically chosen as comparable destinations due to their similarities. Moreover, all DMOs manage their official social media accounts in Spanish. On the other hand, the Summer Vacation Value Report 2018 of TripAdvisor [124] revealed the 10 main international and national destinations for Spaniards and the three main sun and beach destinations used in this study stood out.

\subsection{Content Analysis}

Content analysis is one of the most frequently used techniques to research the promotion of social media tourist destinations. It is the set of procedures that is used to interpret communication products (messages, texts, or speech) that come from previously recorded communication processes that seek to prepare and process relevant data on the very conditions in which those texts have been produced [125].

The qualitative method mainly used in this work focused on observing, directly and inversely, the posts on the official profiles of the selected tourist destinations on Facebook, Twitter, and Instagram, along with the corporate blog of each one. A total of 1721 posts were quantified from the three communities over a 60-day period, from March 1 to April 31 (2018), a period of great tourist influx due to the Fallas and Holy Week - events and festivities that attract large numbers of tourists. The development of these festivities is considered to be the peak season, and it can represent what happens in destinations at other times of the year. In total, exactly 200 publications, taken randomly within the sample, were analysed. They were typed and recorded, and aspects such as general data, tourist destinations, social media, dates, and posts and their content were analysed. The content included the resources used (photos or videos) and what was transmitted, for example, information and suggestions.

The analysis of the data was based mainly on interview transcripts with the support of Atlas.ti software for qualitative analysis. This IT tool is useful for understanding the behavior and strategies of tourism destinations in social media. The analysis of interviews was based on the grounded theory 
approach [126-128]. First, all publications were quantified, and the frequency and types of content shared were the focuses. Finally, the level of engagement was stored and coded. Codification was conducted using the following procedure: these topics were linked with tags (word or sentences) that described the essence of the specific question. This meant that the most relevant topics from previous literature were used to support this proposal. The grounded theory approach, together with the proposed data structure, showed the dynamic relationships between concepts, themes, and dimensions. In the conclusion and discussion sections, the resulting model is compared with the existing empirical framework to highlight the contribution of this research work to the phenomenon of social media management in order to promote destinations.

Furthermore, the aim of this study was to delve further into the most promoted areas in social media and, therefore, six specific categories to be observed in the posts or tweets were defined (Figure 3): nature, tangible heritage, urban landscape, intangible heritage, leisure, sun and beach, businesses, sports, technology, service, tourism agenda, and non-tourist information. Additionally, words such as happiness, thrilling, daring, energetic, imaginative, and charming were used to analyze the alleged emotions transmitted in each of the posts.

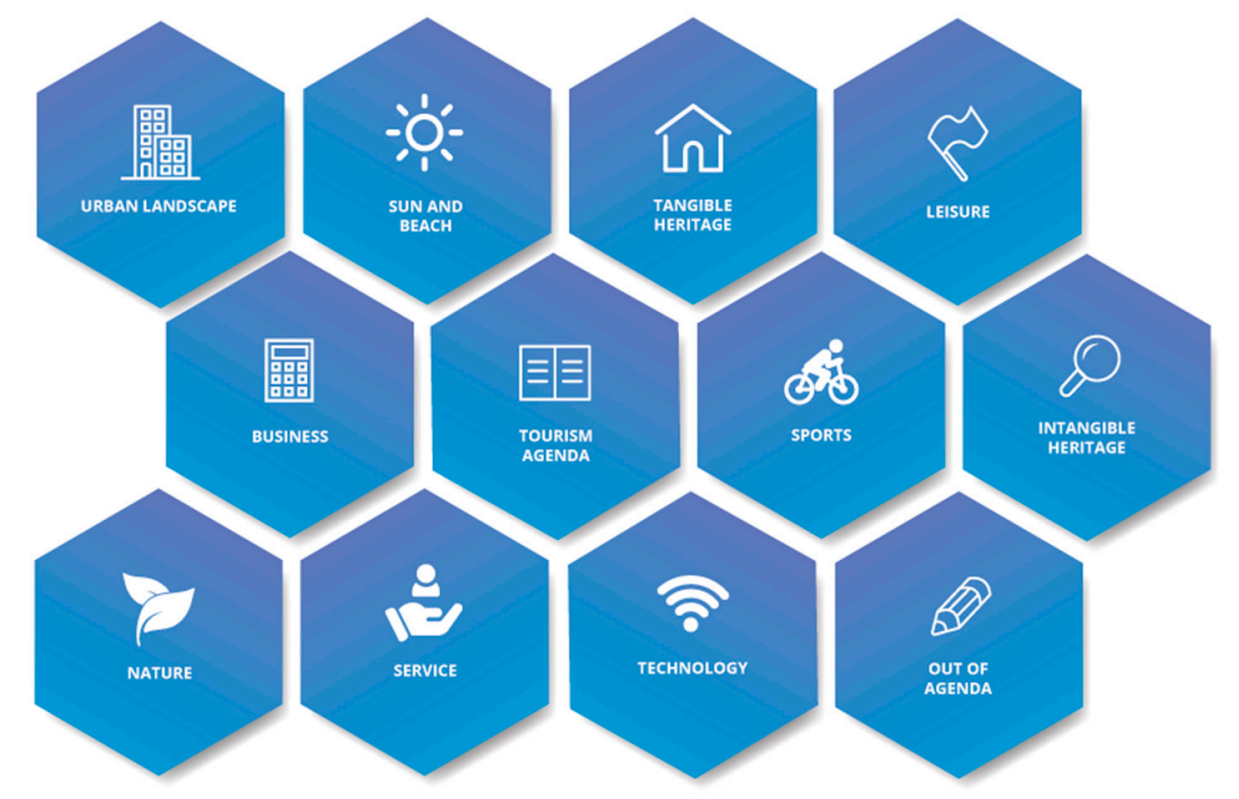

Figure 3. Content categories of posts. Source: Own elaboration based on Paniagua et al. (2019) [129].

The categories and datasheet used for the content analysis were based on the proposal by Paniagua et al. [129]. They were both applied specifically when identifying the theme of each social media post and the types of tourism promoted. In addition, the specific codes selected to determine the above categories were deduced from this study. To ensure inter-coder reliability in this analysis, in accordance with Olson et al [130], two researchers independently coded the content of the official SM accounts studied. After the whole process, a selected number of content units were compared to test the reliability.

\subsection{Interviewing Experts in Promoting Online Destinations}

Interviewing experts is one of the most common qualitative techniques used. In this case, we opted to use interviews to allow in-depth contact to be collected from the architects of the implementation of social media strategies (Table 3). All interviews were carried out by telephone. 
Table 3. Questionnaire and objectives in the interviews. Source: Own elaboration.

\begin{tabular}{|c|c|}
\hline Questions & Objectives \\
\hline $\begin{array}{l}\text { The first questions were on the personal details of the person } \\
\text { being interviewed: name and surname(s), professional profile, } \\
\text { and institution to which they belong. }\end{array}$ & These initial questions identified the experts. \\
\hline $\begin{array}{l}\text { Block 1: How important do you believe it is to implement a } \\
\text { social media strategy for tourist destinations? }\end{array}$ & $\begin{array}{l}\text { The aim of this question was to get an overall picture of how } \\
\text { the interviewees perceived the management of the social } \\
\text { media communication. }\end{array}$ \\
\hline $\begin{array}{l}\text { Block 3: What are the reasons for using social media to a great } \\
\text { extent when promoting a destination (most effective content } \\
\text { for each type of social media, tone etc.)? }\end{array}$ & $\begin{array}{l}\text { The aim of this section was to analyse the interviewees' } \\
\text { perceptions of how a tourist destination should use } \\
\text { social media. }\end{array}$ \\
\hline $\begin{array}{l}\text { Block 4: How would you identify that stakeholders are taken } \\
\text { into account when plotting destination strategies? }\end{array}$ & $\begin{array}{l}\text { This aim of this question was to identify the way in which } \\
\text { stakeholders are considered when promoting a } \\
\text { tourist destination. }\end{array}$ \\
\hline
\end{tabular}

Interviews were based on the triple helix model [131,132], a collaborative model between the private and public sectors and the university. This model was used to analyse new aspects of knowledge based on collaborative relationships between the three entities.

In this case, the triple helix method was fundamental when choosing whom to interview (Figure 4) to ensure that the interviewees represented all stakeholders. In total, eight interviews from experts belonging to the public sector, the private sector, and university were conducted.

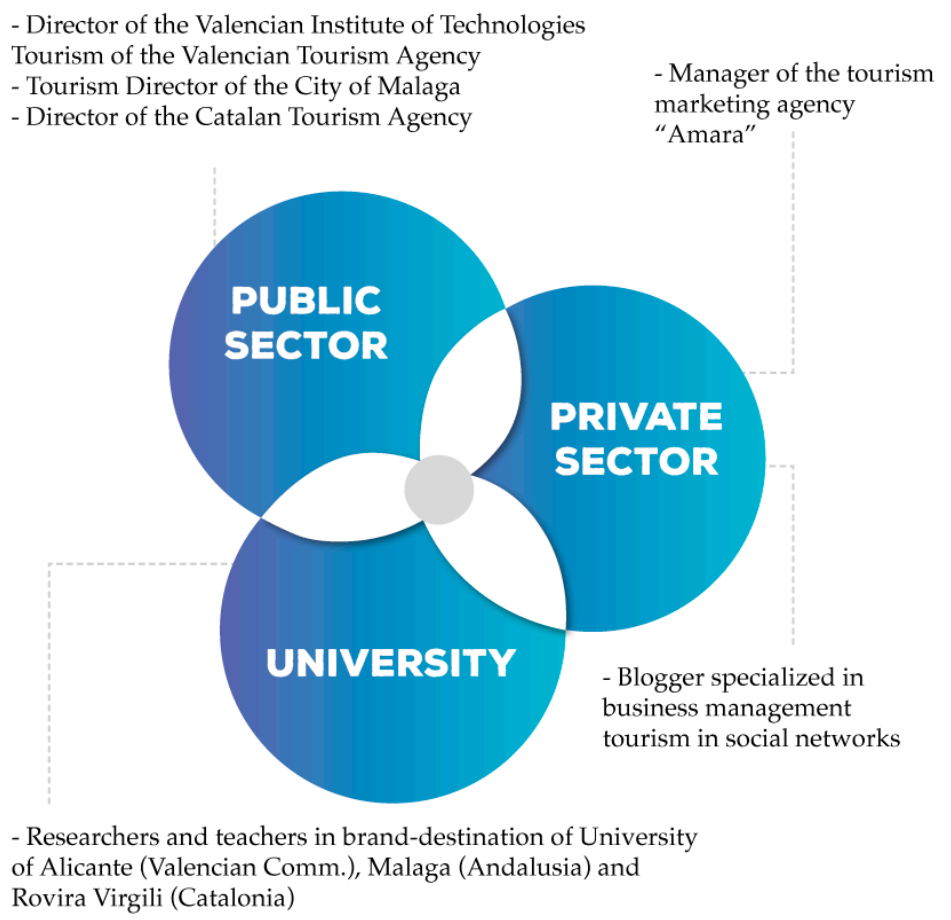

Figure 4. Triple Helix Model and managers interviewed. Source: Own elaboration.

All interviews focused on the strategies used to promote destinations in those spaces, the communications posted, and the interactions obtained. 


\subsection{Analysis Based on Data from Online Tools}

The quantitative part of the analysis was based on different tools that can provide data to be interpreted in order to take stock and put forward proposals. Those tools, or rather the data in social media profiles obtained with them, were used to establish the activity of the users with those profiles and that of their administrators.

It would not be the first time that online tools have been used to analyse the social media activity of tourist destinations, as they have been used to measure data quantitatively and assess the effectiveness of social media engagement [133].

On this occasion, Keyhole was used to analyse Instagram and Fanpage Karma to study the interactivity and impact of the content shared in Facebook. Finally, Twitonomy was used to analyse Twitter content, which provided very interesting data on the use of links or profile visibility, among others.

\section{Results}

\subsection{Type of Content Shared on Social Media}

A content analysis of all posts was warranted to begin to establish the real activity of the official tourism social media accounts of the three destinations and the communication strategies implemented. Therefore, the content was first analysed according to the attitude deduced from the post, and it was noted that nearly half of the posts sought to provide information to the followers, questions were asked in $19 \%$, and, to a lesser extent, queries were answered and thanks given.

Photographs were the most frequent type of content shared, and they were often accompanied by links to official tourism websites (Figure 5). Computer graphics, which were a mixture of image and text, came in third place and were particularly used for events and other types of calendar activity. However, contrary to what might have been expected, videos were not placed in a top spot.

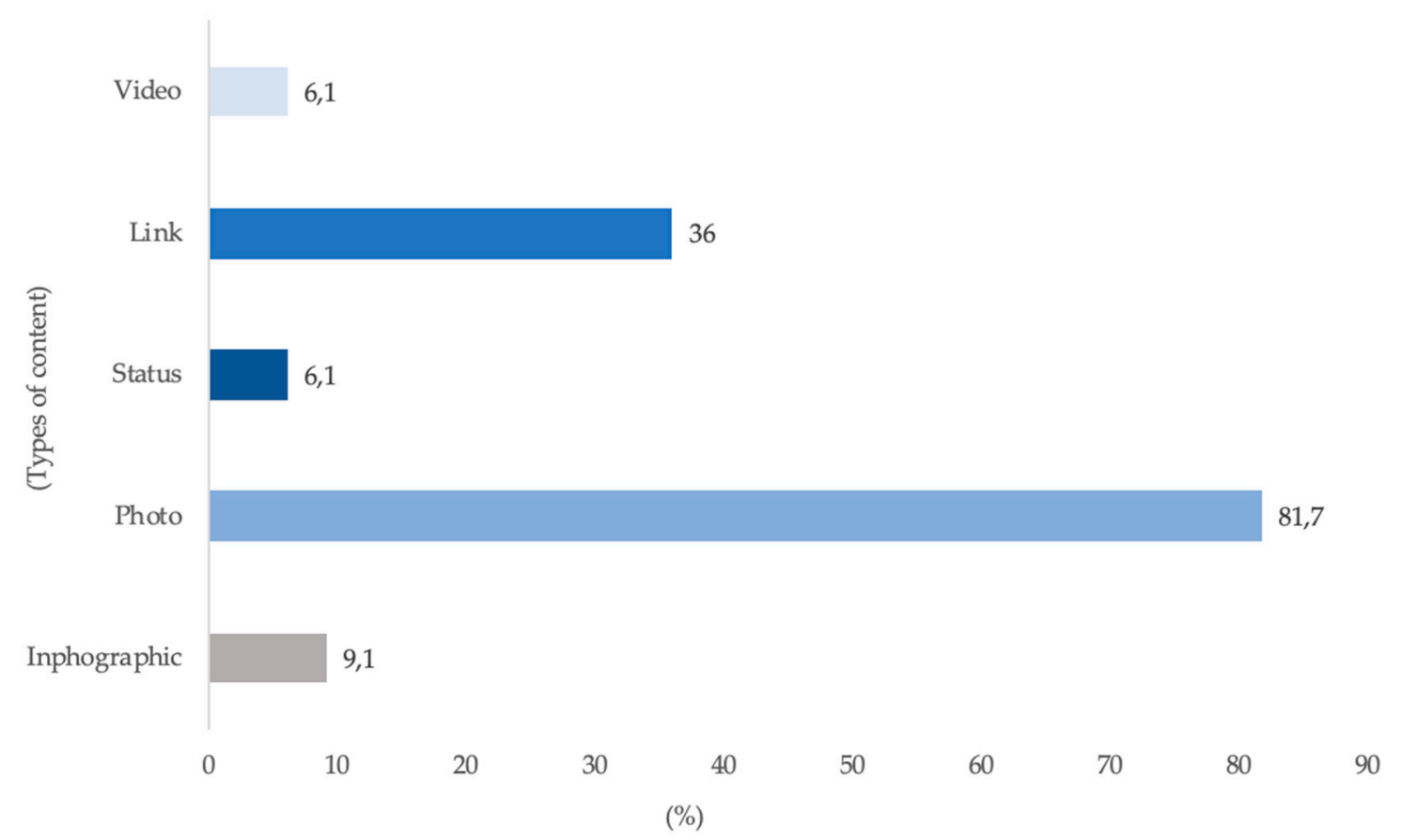

Figure 5. Type of content shared in social media. Source: Own elaboration.

Each theme covered by the posts then had to be considered and analysed in greater depth. Many of the posts (37\%) focused on places that could be visited within each of the destinations in question. Similarly, it should be mentioned that many posts focused on nature $(27.2 \%)$, and $11 \%$ focused on 
architecture. Monuments (10.2\%) were also a central topic of the posts, along with history $(4.1 \%)$ and religion $(8.8 \%)$. Museums featured less $(2.7 \%)$, despite being a major tourist attraction in many cities.

The data showed that over half of the posts referred to popular culture and traditions, an example of which would be the Fallas in Valencia or Holy Week in Andalusia, which were centre stage for longer periods of time in each of the social media analysed. However, gastronomy was also prioritized, and, as a main tourism attraction, in a great number of Spanish cities, it was covered by nearly $35 \%$ of the publications.

Regarding the types of tourism, most posts (58\%) were on cultural and calendar aspects (Figure 6). Likewise, coastal images, followed by beaches, the sea, and the sun were identified as the most commonly promoted aspects (13\%). Just over $10 \%$ of the total posts analysed were about mountains or inland tourism. There were fewer posts with religious, sports, and culinary themes. The tourism industry should continue to promote tourist destinations using iconic and unique experiences, and this should incorporate native flora and fauna as well as distinctive built and natural attractions [3].

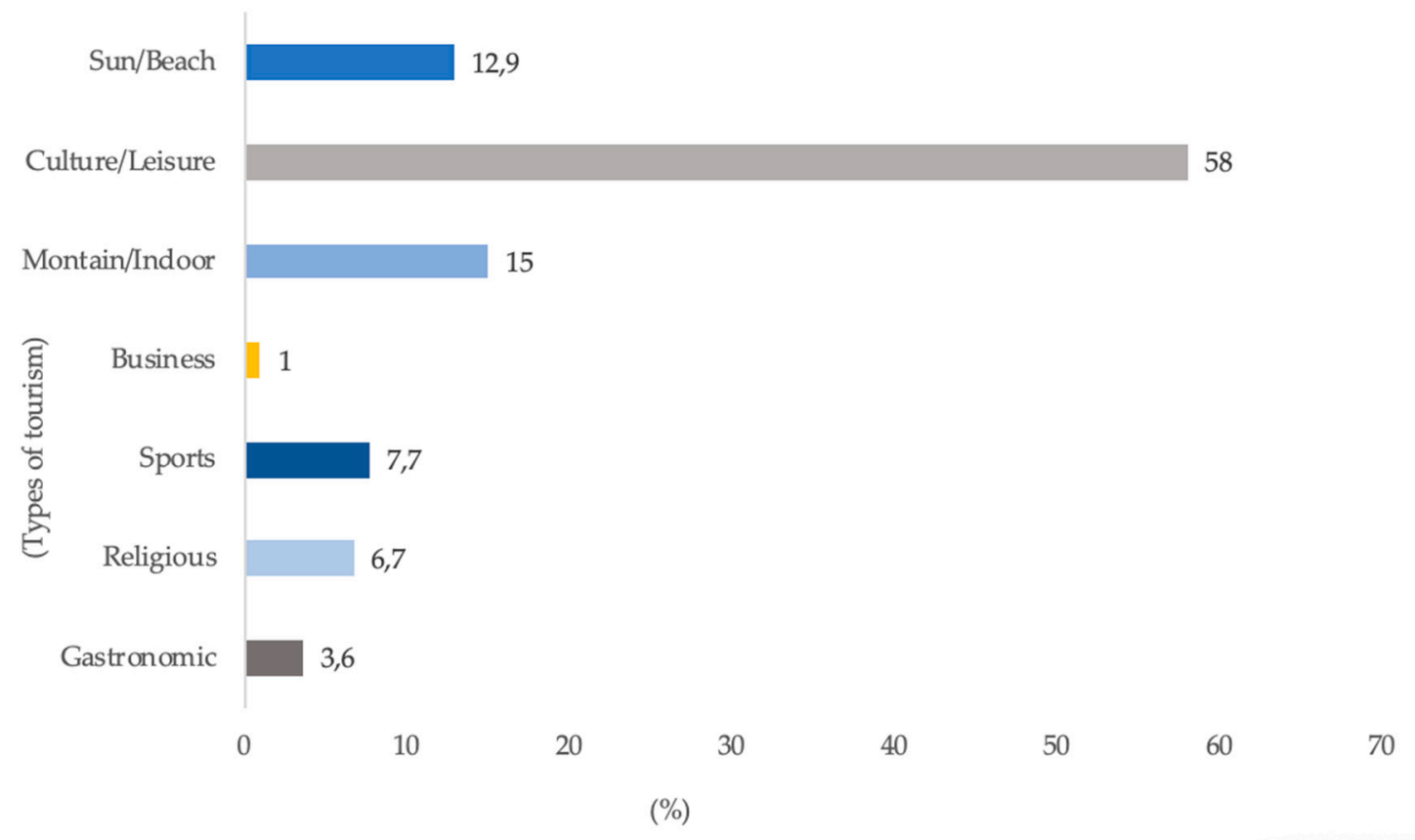

Figure 6. Types of tourism promoted in posts. Source: Own elaboration.

The study also analysed the number of times that new technologies were mentioned, and over $60 \%$ of posts included hashtags or referred to technologies such as "timelapse" in some way.

Hashtags were used to organise events and activities or to organise the information and curious facts about different events and traditions. Posts also recommended and retweeted some television programmes or other third-party content, particularly in Valencia.

A very important aspect to analyse was whether the posts were to do with events on the calendar, contained basic tourist information, or whether they were institutional or had nothing to do with tourism. Over half $(60 \%)$ of the content studied was information of tourist interest. However, $20 \%$ referred to calendar activity. It is also significant that the same percentage was non-tourist information; in other words, the posts were, for example, "Good morning" updates.

In general, the activity of the three official accounts focused on proposing plans or providing information on scheduled events. They also directly recommended visiting a specific place in the selected regions. This means that the studied DMOs prioritise showcasing the tourist attractions over promoting their own brands as a destination and triggering emotional impacts to establish an in-depth relationship with the public. 
Furthermore, the posts mention tourist entities and other local or provincial tourism accounts. This may be because their mutual promotion of each other provides greater visibility.

\subsection{Expert Assessment of the Promotion of Tourist Destinations}

It was considered relevant to compare the data collected in the content analysis period with the assessments of experts whose day-to-day work means they are familiar with promoting tourist destinations through social media.

The experts began by assessing the importance of implementing a strategy to promote tourist destination using a particular type of media. They were asked why they considered the management of the social media profiles of the destinations to be essential. There was a great variety of answers, which can be seen in Figure 7.

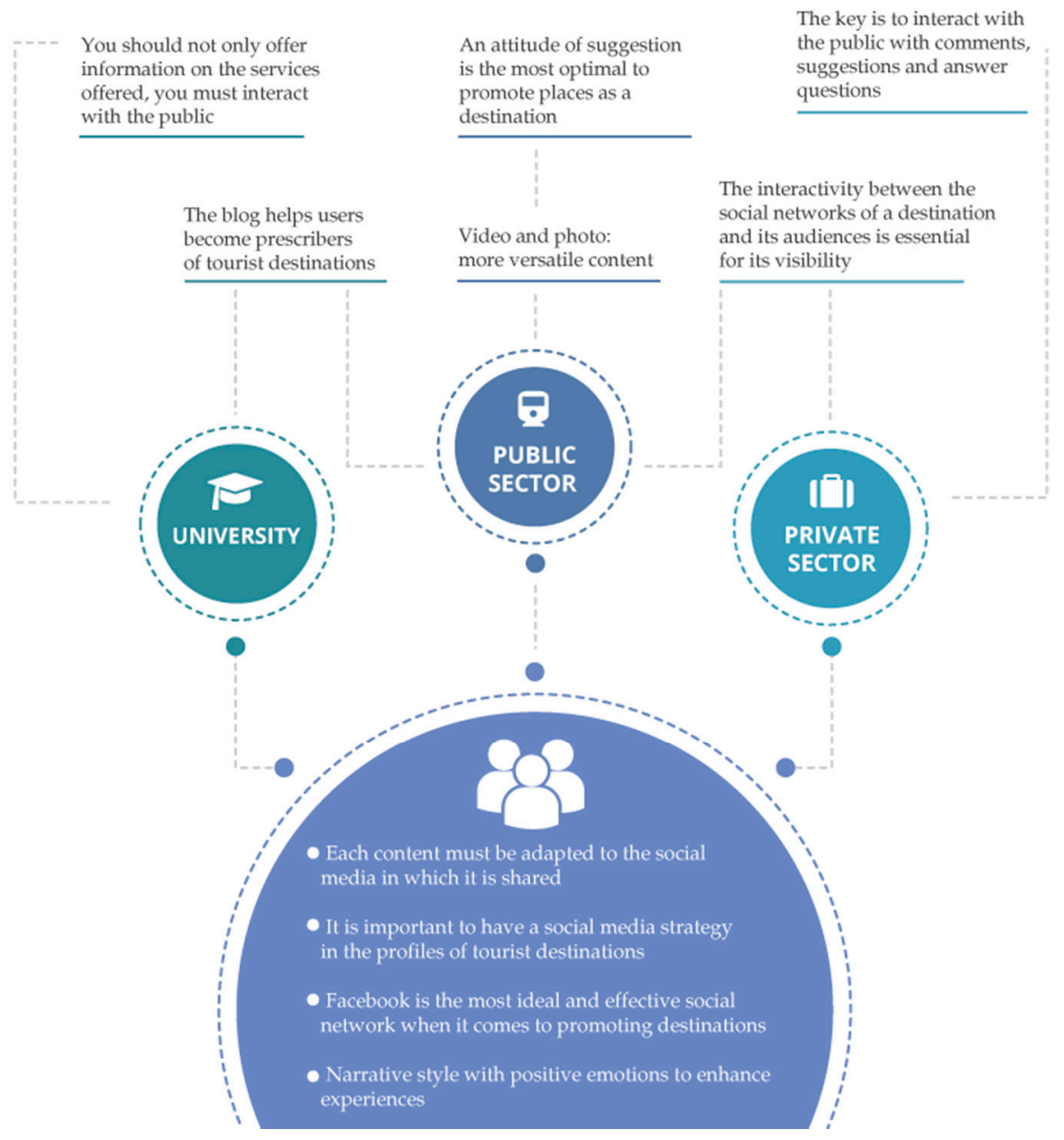

Figure 7. Experts' opinions according to sector. Source: Own elaboration.

The following questions focused on the central area of the research, aiming to analyse the content. First, the majority of the experts agreed that video is the most effective type of content to share on the official profiles of destinations, which coincides with the forecast of the 12th Cisco Visual Networking Index [134], which stated that video would lead the way and would represent $70 \%$ of all Internet traffic in Spain by 2021, compared with $60 \%$ in 2016. However, they stressed that each type of content has to adapt to each social media platform.

Facebook was the social platform that the experts identified as being the most appropriate and effective when promoting tourist destinations. The academics also considered that in addition to 
information being offered on the available services, interactivity with the general public should be also facilitated and enhanced.

The professionals of the public sector also expressed their opinions on the most effective types of content to use according to the attitude of the message. It was highlighted that a suggestive attitude is the most optimal way to promote a place as a destination. Meanwhile, the comments of the private sector were more decisive. Even though they differed in that regard, they all expressed the same opinion: that experiences need to be enhanced by using a narrative style including feelings and experiences, for example, words such as happiness, thrilling, and daring.

The experts were encouraged to comment on the importance of sharing information from an official and specialist tourism blog through the official profiles of the destinations. Above all, both the academics and the Public Sector professionals considered that tourists are demanding more information on destinations to aid them in preparing their own travel plans, and blogs greatly help to create loyalty if useful information can be found there. Thus, blogs help to enrich the narrative and convert users into influencers based on their experiences.

An aspect in which interviewees from the private and public sectors coincided was that interactivity between the social media profiles of the destinations and their audiences is fundamental for their visibility. Thus, regarding the importance of the customer service channel, they considered it to be important but not vital.

Lastly, all experts interviewed agreed that tourist destinations use social media, above all, as an information channel to disseminate tourist content rather than a way of interacting with tourists to promote specific services of the tourist industry or deal with queries.

\subsection{Data Obtained Using Online Tools}

Within the period analysed, the images, links, and videos were the types of content with the most comments, reactions, and shares on Facebook (Table 4).

Table 4. Comparison of data obtained using online tools on Facebook. Source: Own elaboration.

\begin{tabular}{cccc}
\hline Regions & No. of Fans & Commitment & Interaction with the Posts \\
\hline Andalusia & $71 \mathrm{~K}$ & $0.41 \%$ & $0.22 \%$ \\
\hline Valencia & $194 \mathrm{~K}$ & $0.22 \%$ & $0.11 \%$ \\
\hline Catalonia & $508 \mathrm{~K}$ & $0.87 \%$ & $0.39 \%$ \\
\hline
\end{tabular}

Catalonia had the greatest number of followers with over two posts per day and a very strong weekly evolution (23\%). The interaction was striking, with $0.87 \%$, compared to the Facebook analysis of other communities. Catalonia nearly always posted images on Facebook, as was the case with the other regions analysed.

On Twitter (Table 5), Valencia was in second place with a large number of fans; however, it was the one that posted the most tweets, on average. The past performance of the account of Catalonia was very different; it obtained more "likes" per post even though it had fewer fans.

Table 5. Comparison of data obtained using online tools on Twitter. Source: Own elaboration.

\begin{tabular}{ccccc}
\hline Regions & No. of Fans & Average Number of Tweets & Average Number of Likes & Average Number of Retweets \\
\hline Andalusia & $94 \mathrm{~K}$ & $51.9 \mathrm{~K}$ & 21.2 & 560 \\
\hline Valencia & $96.7 \mathrm{~K}$ & $23.1 \mathrm{~K}$ & 20.1 & 6.2 \\
\hline Catalonia & $66 \mathrm{~K}$ & $17.8 \mathrm{~K}$ & 27.6 & 24.1 \\
\hline
\end{tabular}

Valencia was the winner in terms of the number of fans, but the fact that it did not obtain many retweets was remarkable. Retweeting from the official Twitter accounts of the three destinations was to 
local or regional tourism accounts, which could be to promote each other. The main type of activity conducted by all of them was, above all, showcasing plans through Twitter.

On Instagram (Table 6), significant engagement was achieved. In the same way as with the results obtained from the content and expert analysis, images were the content that best functioned on Instagram and, specifically, carrousel photos, which are several images put together in a single post, were used.

Table 6. Comparison of data obtained using online tools on Instagram. Source: Own elaboration.

\begin{tabular}{cccccc}
\hline Regions & No. of Fans & $\begin{array}{c}\text { Average Number } \\
\text { of Likes }\end{array}$ & $\begin{array}{c}\text { Average Number } \\
\text { of Comments }\end{array}$ & $\begin{array}{c}\text { Average } \\
\text { Engagement }\end{array}$ & Total Posts \\
\hline Valencia & 28,839 & 28,558 & 3.4 & 750 & 993 \\
\hline Andalusia & 28,646 & 560 & 5.8 & 400 & 1071 \\
\hline Catalonia & 248,712 & 5035 & 24.1 & 8000 & 2580 \\
\hline
\end{tabular}

Catalonia was the region that achieved the greatest engagement on Instagram with an average of 5035 likes and 24.1 comments per post.

Quantitative analysis allowed us to determine the content generation focus of these official tourism accounts and how they use their own icons or attributes to promote destinations. @ComunitatValenciana suggested the use of the hashtag \#navidadenvivo or \#semanasanta for their followers, while @CatalunyaExperience chose \#Terresdelebre. The most popular hashtags are shown in the following Figures 8-10. All regions used hashtags chosen according their popularity and their coincidence with the names of specific cities, for example, \#tarragona in Catalonia or \#sevilla in Andalusia.

\section{\# Hashtags most used}

$\begin{array}{lc}\text { \#mediterráneoenvivo } & 180 \\ \text { \#planes } & 64 \\ \text { \#quizcv } & 50 \\ \text { \#semanasanta } & 11 \\ \text { \#btt } & 9\end{array}$

\#gastro

\#cvquiz

\#conniños

\#navidadenvivo

\#receta

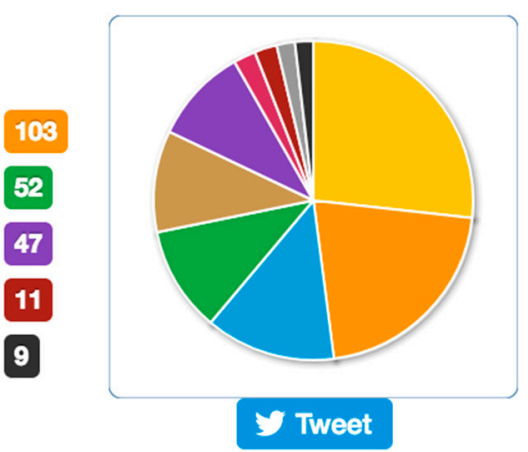

Figure 8. The most frequently used hashtags by the DMO in Valencia. Source: In-house elaboration with support of Twitonomy.

\section{\# Hashtags most used}

$\begin{array}{llll}\text { \#incostabrava } & 91 & \text { \#barcelona } & 61 \\ \text { \#catalunya } & 55 & \text { \#catalunyaexperience } & 51 \\ \text { \#bondia } & 50 & \text { \#terresdelebre } & 50 \\ \text { \#girona } & \mathbf{3 4} & \text { \#tarragona } & \mathbf{3 0} \\ \text { \#deltadelebre } & 30 & \text { \#ebre } & \mathbf{2 9}\end{array}$

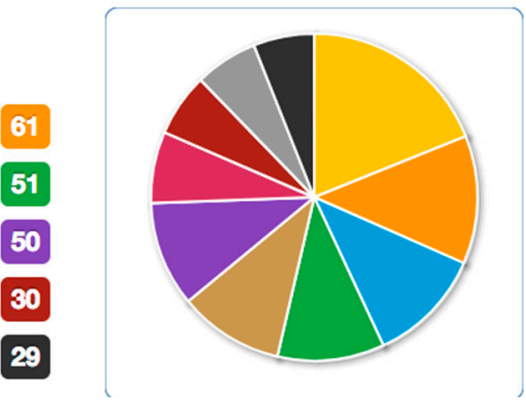

Figure 9. The most frequently used hashtags by the DMO in Catalonia. Source: In-house elaboration with support of Twitonomy. 


\section{\# Hashtags most used}

\begin{tabular}{lr} 
\#viveandalucía & 861 \\
\hline \#intensamente & 288 \\
\hline \#málaga & 168 \\
\hline \#córdoba & 158 \\
\#granada & 186 \\
\end{tabular}

\#andalucía

\#sevilla

\#cádiz

\#instagram

\#huelva

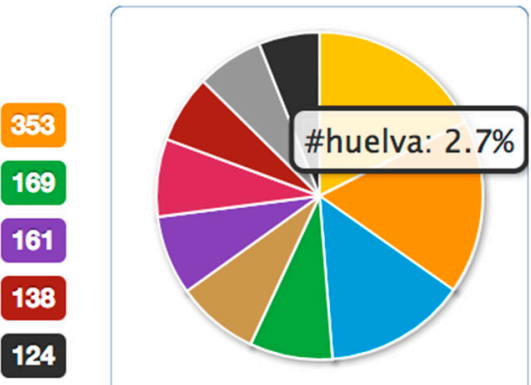

Figure 10. The most frequently used hashtags by the DMO in Andalusia. Source: In-house elaboration with support of Twitonomy.

The information provided by the following word clouds (Figures 11-13) generated by the online analysis tool also shows that hashtags, such as \#Jornadas, \#Sant, \#festes, \#festival, \#fiesta, and \#SemanaSantaAndalucía, were used to promote festivities and events in the period analysed.

Picture Nacional Cadaqués Montserrat ¡Buenas Vall Benet molt Costa Roser Barcelona Val pirineus Més amb Mar nit Ruta pregunta Gaudi Jornades dia Catalunya Pau vespre Pirineu Visit otoño naturales Empordà Turisme Boí Ara Guia alta Sant Jomadas Garrotxa Festes Girona Lleida celebra gran Daurada tardor Brava Terres Ribagorça Vi especial

Figure 11. Cloud tag of the words used most frequently on Facebook by Catalonia. Source: In-house elaboration with support of FanPage Karma.

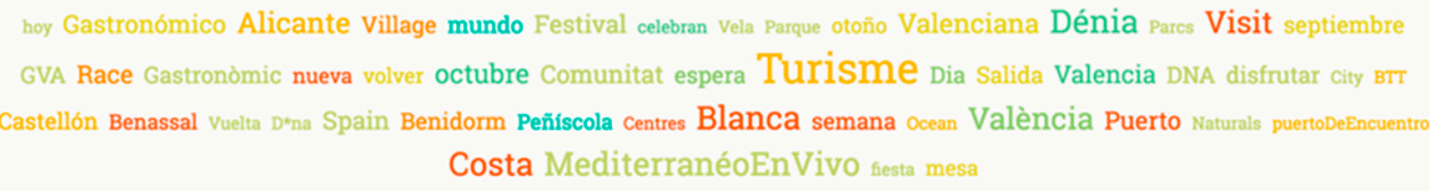

Figure 12. Cloud tag of the words used most frequently on Facebook by Valencia. Source: In-house elaboration with support of FanPage Karma.

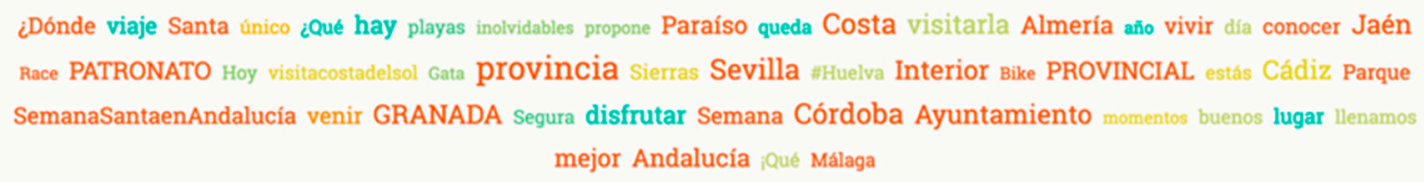

Figure 13. Cloud tag of the words used most frequently on Facebook by Andalusia. Source: In-house elaboration with support of FanPage Karma.

The largest words are the most used by destinations and the smallest are less used. The words in the same colour usually go together in a post.

It was found that some concepts are common among all social media strategies to promote image, mainly cities, moments, or events of special tourist interest and some motivations for tourists when sharing posts about nature, interior aspects, bikes, sailing, or gastronomy. They also tried to link content with positive feelings related to travel: enjoying, relaxing, good times, etc.

The hashtags and their engagement also drew on resources related to knowing the types of social media content from official account of tourist destinations valued most by tourists. Top hashtag engagement was associated with a useful plan such as \#relax or \#spanatural, unique places to visit 
such as \#granada, \#costablanca, and \#acantilados, and festivities or events, such as \#montserrat or \#santatecla (Figures 14-16).

\section{Top Hashtags by Engagements}

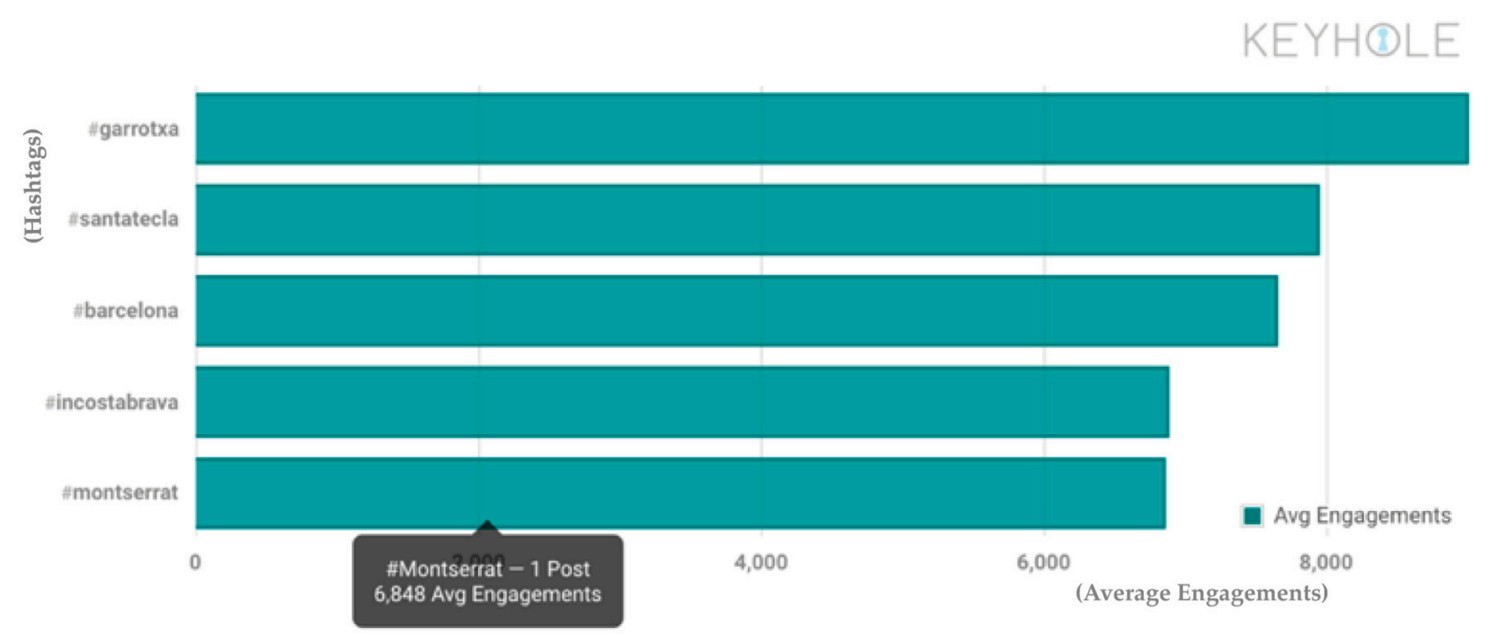

Figure 14. Engagement with hashtags from Catalonia. Source: In-house elaboration with support of Keyhole.

\section{Top Hashtags by Engagements}

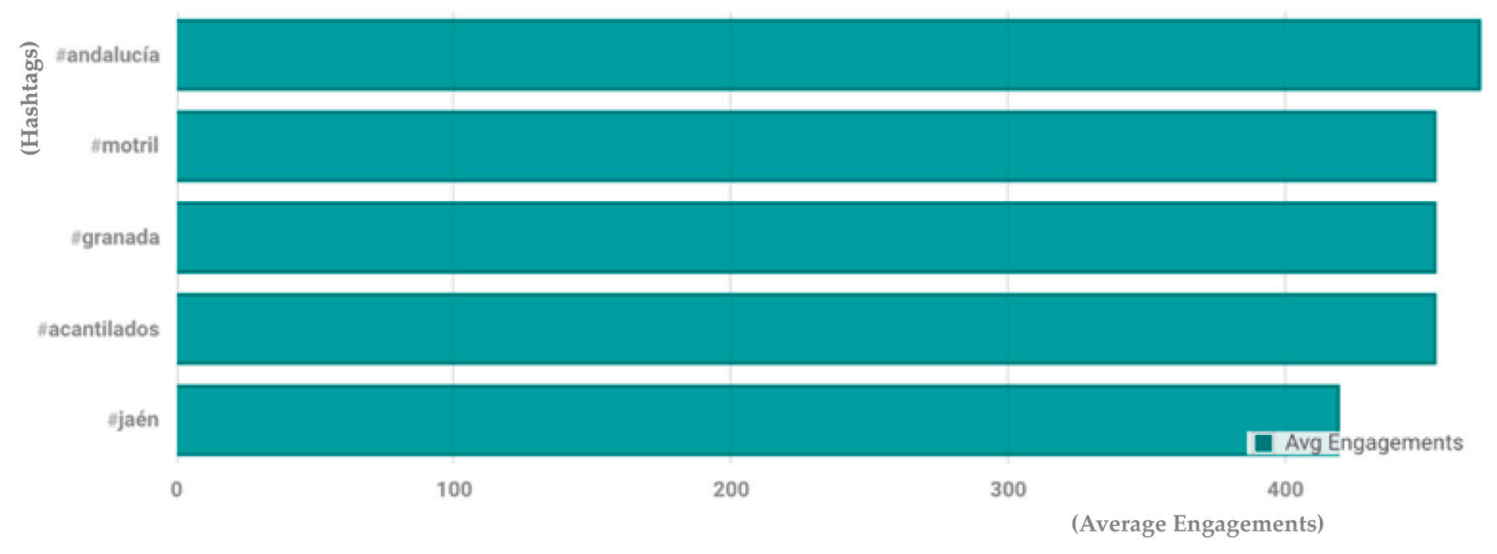

Figure 15. Engagement with hashtags from Andalusia. Source: In-house elaboration with support of Keyhole.

Thus, the great capacity of interactions to drive a destination brand is not being optimized. An association between interactions (likes and comments) and followers was predicted using the Chi-Square Test of Independence $(\alpha=0.05)$. Since the $p$-value was less than our chosen significance level $\alpha=0.05$, we can reject the null hypothesis and conclude that there is an association between the number of followers and the total number of interactions (likes and comments). 


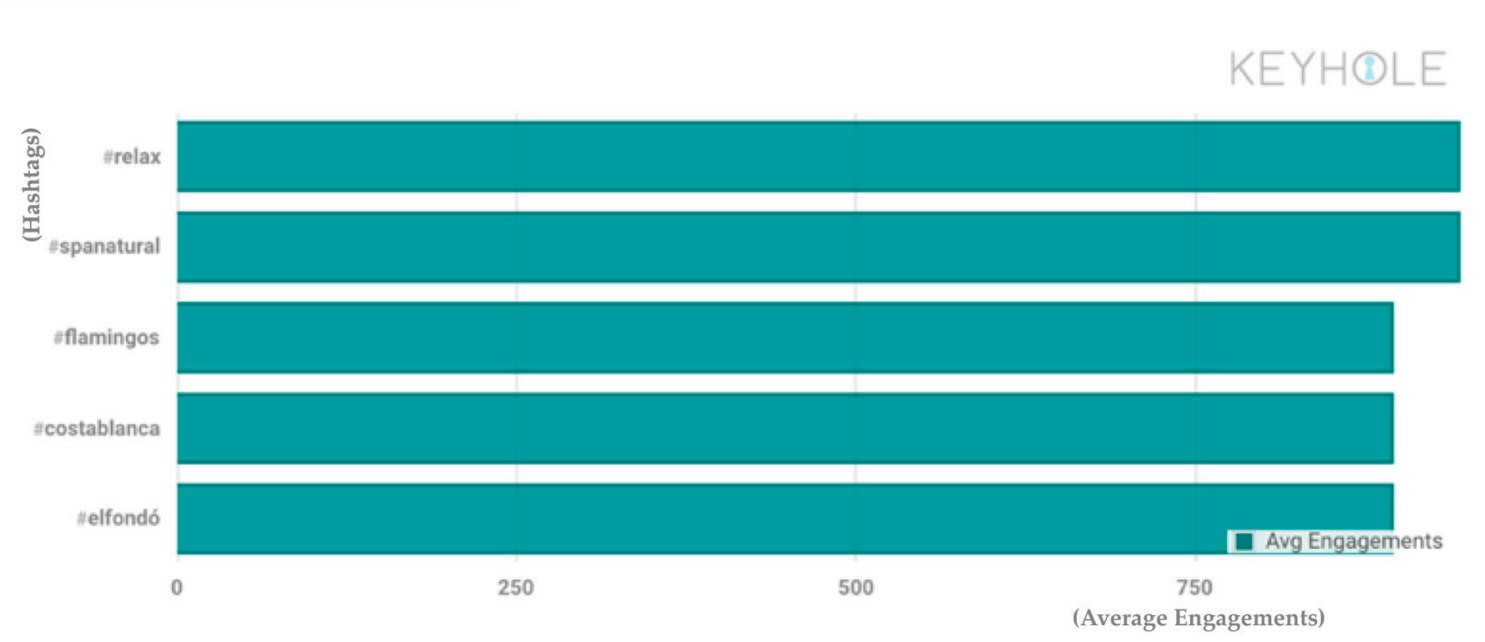

Figure 16. Engagement with hashtags from Valencia. Source: In-house elaboration with support of Keyhole.

\section{Discussion and Conclusions}

This research work provides a number of new insights into the field of destination management through social media, paying particular attention to image creation and promotion as well as stakeholder contribution. First, we revealed that social media effort is concentrated on showing, persuading, and attracting tourists to the icons and attributes of a destination. In some way, destination image is based on this and the social media content reproduces and enhances these features. However, tourist sites and monuments share centre stage with characteristic events and traditions. This finding is in line with studies by Cantos et al. [38] and Bregoli [47] that highlighted the cultural and natural heritage of a region as being fundamental attributes that define its identity and contribute to the formation of its image as a tourist destination. Moreover, special emphasis is placed on experiences, how to enjoy the destination, and the ways in which to do this, depending on who the tourist is (familial, focused on nature, etc.). Consequently, the first hypothesis was validated, giving further support to previous literature results. Baloglu and McCleary [14] highlighted these components as being key factors in the destination image, and more recent research works showed that these factors make up the core of the content on social media $[17,18,22,30]$.The value of events was also suggested by Ghazali and Cai [6], and Pike [35] drew the same conclusion about experiences as this study.

Second, the content analysis and statistical correlations support hypothesis 2 . Social media platforms are interactive and dynamic, and they allow destinations to manage their image $[15,68]$. The content producers are aware of the strategic contribution of social media for their image, and they try to generate useful content for tourists. The empirical analysis provided evidence that more than $20 \%$ of the content shared is focused on proposing plans or providing information about scheduled events. We found that the number of followers, as a direct consequence of attractive content, rather than the number of posts, is not a major factor in whether a positive relation with interactions and interest in the destination on their social media is attained. This issue agrees with the findings of Sanders and Stappers [68] and Luo and Zhong [72] regarding the types of social media content that ensure customer interest and positive effects on relations between users and brands, thereby leading to greater levels of credibility and loyalty, but it also highlights that DMOs should be consistent in creating value in social media to create a positive image for all stakeholders [17,66-68].

All of the abovementioned information also answers our first two research questions. This study provides a better understanding of how social media is used by destinations by identifying the main common topics and strategies of engagement with tourists. 
It should be stressed that there were very similar behaviour patterns in the management of social media of the three accounts analysed. The accounts focused on places of interest in the image strategies; moments or events of special tourist interest; lifestyle attributes or motivations for tourists, such as biking, sailing, or gastronomy, and the use of words to link positive feelings related to travel. As a result of the content analysis, the interactions of the posts in social media were found to differ from what they could be; this has also been a common finding in other studies [18,71]. Referring to content shared by each official account, large numbers of photographs, banners, and images were found with a lot of reactions, comments, and shares. Despite this, videos were the type of content that stood out with regard to interactions, albeit to a lesser extent because much fewer were posted. Videos were the most frequently used type of content. According to the experts interviewed, they are the most effective type of content to share on the official profiles of the destinations. Furthermore, videos are the most reliable way to provide information and are relevant for users who browse the web [135]. It is important for the tourist destinations to continue working on good social media management practices due to their interactive capacity and the influence they have on tourist decision-making [71,77]. This finding is in line with Huertas and Marine-Roig [17], and it also highlights that DMOs should be consistent in generating valuable content in social media to create a positive image among all stakeholders.

Furthermore, the promotion of the whole destination overall should be further encouraged, rather than focusing on the cities separately, while the image continues to be decisive in the differentiation of these and is crucial for value creation. Regarding engagement, it was shown that tourists are motivated to participate when a destination offers a broader and more varied range of attractions and activities, the community interaction is higher, and the content is relevant for their interests and profile (style of travelling). Likewise, gaining tourist involvement through content related to destinations is suggested as an effective resource for building and promoting a destination's image. As result of this, attention should be paid to content generated by tourists on destinations' official accounts as well as outside of these [22].

These conclusions coincide with and complement those of Stepchenkova and Li, [7], because they reinforce the identification of key issues for tourists related to destination choice. Moreover, in line with Huertas and Marine-Roig [17] and Leung et al. [15], it should be emphasised that being present on social media is a great way to promote destinations at a very low price. In any event, this study, as also stated by Usakli et al [19], shows that destinations are still facing challenges in using social media management to showcase their potential and achieve greater success with their strategies. The analysis allows us to conclude that further analysis is needed due the exploratory focus of this study.

The final finding is related to UGC (RQ4), and it is one of the main contributions of this study. Previous literature focused on how UGC is a key factor for managing destination image and general strategies [5,83-85,136]. UGC is a fundamental way to involve tourists in forming image destination through social media [12,71,74,77,137]. It allows their needs and expectations [78-80] regarding their experience in each destination to be understood and indicates the types of content they value in social media from official accounts and DMOs in charge of promoting destinations [21].

However, the extent analysis was carried out on collaborative and external platforms, which means sources outside of destinations' official accounts. This is the main difference and the source of the novelty in the analysis of the UGC issue in this study. Tourists generate content for destinations' social media as result of posts proposed by DMOs. Currently, destinations are aware of content created by users $[13,85]$, but they are not working hard enough on motivating tourists to contribute to the formation and improvement of a destination's image. This factor cannot be analysed separately, and an integrative and coordinated effort should be used as a brand strategy. As Hidalgo Alcazar et al. [136] discerned, "tourism destinations need to disseminate favorable experiences to tourists, and these experiences include advice and comments from other travellers" (p.162). However, as claimed in this study, the benefits from including evaluations and experiences of tourists on destinations channels can reinforce and improve the engagement with and attractiveness of destinations. Thus, this content becomes a source of information and recommendations since tourists use it to share 
their experiences [138]. Moreover, the content generated by users is actually the key to gaining more interactions [22], and this content is more reliable than a destination's own content [81]. To sum up, one of the keys to the promotion of a tourist destination is the content generated by users. Consequently, it is proposed that DMOs should strengthen and prioritise two-way communication with tourists to better promote their image. It possible to take a similar approach to that described by Roca [56], who recommended the use of a concerted effort to create a structured model for image promotion in order to obtain maximal results from social media.

Last, but not least, some reflections about stakeholders are presented. Stakeholders are a main issue of the initial focus of this study. Although tourism literature has widely discussed the roles of stakeholders and their capacity to construct a positive destination image [49,91,100-102], this study introduced stakeholders' roles in the interactivity of social media. Moreover, the application of the triple helix model for the analysis of stakeholders provides a clear distinction from previous literature. The interviews carried out allowed us to answer RQ5. A better understanding of the crucial role of stakeholders in content creation was also obtained. Most research works have focused on the role of tourists as central stakeholders, but other groups involved in destination activity should be taken into account, especially if the destination image is being analysed [29,98]. Based on the results, different stakeholders are valuable sources of trust, and content generated by them could attract potential tourists and contribute to the promotion of a destination. An interesting insight drawn from the study is that all stakeholders seem to be related and, consequently, they do not have to be approached separately. For example, it appears that universities can be a key partner for the creation and promotion of a destination's image in collaboration with DMOs and can be used as a source of knowledge for tourists.

In short, this paper demonstrates that social media platforms are strategic tools for destination branding and image formation and promotion. However, the novel factor of this study compared with previous literature is the acknowledgement that stakeholders play a main role. Tourists are not the only group to take into account. DMOs should have a wide and holistic vision of stakeholders. Therefore, their identification should be aligned with their involvement in social media strategies to achieve the goal of differentiation through a destination's image. If social media has an impact through its content, user contributions could increase and destinations will be able to exploit their attractions (icons, events, experiences) further and improve their positioning in the minds of tourists. Further, the insights provided in this exploratory study demonstrate the challenges that DMOs face in social media management.

\section{Practical Implications}

This research work provides the main practical implications for destination image management. DMOs can better manage and differentiate their social media content strategy through useful content, and the reinforcement of icons from the destination contributes highly to the formation of an image. Likewise, based on experiences and connections between a style of travelling and the type of content can improve performance in terms of a destination's competitive advantage. User-generated content is essential for promotional and marketing activities, as it is an effective way to create trust in tourists' minds. However, the involvement of all stakeholders should be appreciated and taken into account to achieve a successful result for image promotion. The analysis of destination image and the understanding and management of stakeholders' contributions indicated that operational strategies should be established to improve a destination's image promotion and to establish a deep relationship with the public.

\section{Limitation and Future Research Directions}

The current study contributes to the importance of social media in destination marketing and image formation from the perspective of stakeholders in several ways. To delve into a better understanding of the phenomenon it could be suggested to include the visitor point of view. 
It is likely that not all factors that influence the creation of the image of a tourism destination by visitors using social media management were included in the conceptual model of this research.

Third, the active role of social media and the benefits associated with its incorporation into marketing and communication strategies needs to be further examined, since the literature shows that companies have not achieved the full potential of social media, not to mention the limited research that has been done in the tourism sector [139-141].

In addition, despite the results of this exploratory approach with a mixed method, further studies are required.

Some additional areas of study are proposed. Future research could explore how visitors perceive tourist destinations through social media using surveys. This could provide the opportunity to establish a comparison between visitors and the public and private sectors. Secondly, future scholars could analyse the importance of the dimensions of process quality and the quality of results. For example, longitudinal research should emphasize the interactions that occur between the public and the social media of tourist destinations, as this could ultimately give more information about image creation. Social media allows effective communication of destination brands and the development of a relationship between users and these brands [34].

Finally, future studies might consider the association between image representation and other factors that could lead customers to decide to visit one tourist destination over another.

Author Contributions: C.d.1.H.-P., E.M.-C., P.P.I.-S. and C.J.-M. contributed equally to this paper. All authors have read and agreed to the published version of the manuscript.

Funding: This research has received funds from Plan Propio Universidad de Málaga.

Conflicts of Interest: The authors declare no conflict of interest.

\section{References}

1. Instituto Nacional de Estadística. Estadística de movimientos Turísticos en Fronteras (FRONTUR); Instituto Nacional de Estadística: Madrid, Spain, 2019.

2. Buhalis, D.; Law, R.; Law, R. Progress in information technology and tourism management: 20 years on and 10 years after the Internet-The state of eTourism research. Tour. Manag. 2008, 29, 609-623. [CrossRef]

3. Hughes, M.; Martin, S.L.; Morgan, R.E.; Robson, M.J. Realizing Product-Market Advantage in High-Technology International New Ventures: The Mediating Role of Ambidextrous Innovation. J. Int. Mark. 2010, 18, 1-21. [CrossRef]

4. IAB Spain. Annual Social Media Report. 2018. Available online: https://iabspain.es/estudio/estudio-anualde-redes-sociales-2018/ (accessed on 1 September 2019).

5. Marine-Roig, E.; Clavé, S.A. A detailed method for destination image analysis using user-generated content. Inf. Technol. Tour. 2016, 15, 341-364. [CrossRef]

6. Ghazali, R.; Cai, L. Social Media Sites in Destination Image Formation. In Tour. Social Media: Transformations in Identity, Community and Culture (Tourism Social Science Series, Vol. 18); Emerald Group Publishing Limited: Bingley, UK, 2014; pp. 73-86. [CrossRef]

7. Stepchenkova, S.; Li, X. (Robert) Destination image: Do top-of-mind associations say it all? Ann. Tour. Res. 2014, 45, 46-62. [CrossRef]

8. Chen, C.-C.; Lai, Y.H.; Petrick, J.F.; Lin, Y.-H. Tourism between divided nations: An examination of stereotyping on destination image. Tour. Manag. 2016, 55, 25-36. [CrossRef]

9. Lee, B.; Lee, C.-K.; Lee, J. Dynamic Nature of Destination Image and Influence of Tourist Overall Satisfaction on Image Modification. J. Travel Res. 2013, 53, 239-251. [CrossRef]

10. Huete-Alcocer, N.; Ruiz, V.R.L. The role of destination image in tourist satisfaction: The case of a heritage site. Econ. Res. Ekon. Istraživanja 2019, 1-18. [CrossRef]

11. Shani, A.; Wang, Y.; Hudson, S.; Moreno-Gil, S. Impacts of a historical film on the destination image of South America. J. Vacat. Mark. 2009, 15, 229-242. [CrossRef]

12. Camprubí, R.; Guia, J.; Comas, J. The new role of tourists in destination image formation. Curr. Issues Tour. 2013, 16, 203-209. [CrossRef] 
13. Llodrà-Riera, I.; Martínez-Ruiz, M.P.; Jiménez-Zarco, A.I.; Izquierdo-Yusta, A. A multidimensional analysis of the information sources construct and its relevance for destination image formation. Tour. Manag. 2015, 48, 319-328. [CrossRef]

14. Baloğlu, Ş.; McCleary, K.W. A model of destination image formation. Ann. Tour. Res. 1999, 26, 868-897. [CrossRef]

15. Leung, D.; Law, R.; Van Hoof, H.; Buhalis, D. Social Media in Tourism and Hospitality: A Literature Review. J. Travel Tour. Mark. 2013, 30,3-22. [CrossRef]

16. Özdemir, G.; Çelebi, D. Reflections of Destinations on Social Media. In Regional Economic Development in Russia; Springer Science and Business Media LLC: Berlin, Germany, 2015; pp. 243-249.

17. Huertas, A.; Marine-Roig, E. Destination Brand Communication Through the Social Media: What Contents Trigger Most Reactions of Users? In Proceedings of the Information and Communication Technologies in Tourism, Lugano, Switzerland, 3-6 February 2015; pp. 295-308.

18. Hays, S.; Page, S.J.; Buhalis, D. Social media as a destination marketing tool: Its use by national tourism organisations. Curr. Issues Tour. 2013, 16, 211-239. [CrossRef]

19. Usakli, A.; Koç, B.; Sönmez, S. How 'social' are destinations? Examining European DMO social media usage. J. Destin. Mark. Manag. 2017, 6, 136-149. [CrossRef]

20. I Agustí, D.P. Characterizing the location of tourist images in cities. Differences in user-generated images (Instagram), official tourist brochures and travel guides. Ann. Tour. Res. 2018, 73, 103-115. [CrossRef]

21. Munar, A.M. Social Media Strategies and Destination Management. Scand. J. Hosp. Tour. 2012, 12, 101-120. [CrossRef]

22. Iglesias-Sánchez, P.P.; Correia, M.B.; Jambrino-Maldonado, C.; Heras-Pedrosa, C.D.L. Instagram as a Co-Creation Space for Tourist Destination Image-Building: Algarve and Costa del Sol Case Studies. Sustainability 2020, 12, 2793. [CrossRef]

23. Iglesias-Sánchez, P.P.; López-Delgado, P.; Correia, M.B.; Jambrino-Maldonado, C. How do external openness and R\&D activity influence open innovation management and the potential contribution of social media in the tourism and hospitality industry? Inf. Technol. Tour. 2020, 1-27. [CrossRef]

24. World Tourism Organization. Tourism Market Trends: Europe. In WTO Commission for Europe; World Tourism Organization: Madrid, Spain, 1998; pp. 15-32.

25. Ruiz, A.V.; Olarte, R.; Iglesias, V. Evaluación de los destinos turísticos en función de su valor de marca. In Actas del XI Encuentro de Profesores Universitarios de Marketing; Universidad de Valladolid: Valladolid: Valladolid, Spain, 1999; pp. 427-450.

26. Murphy, P.; Pritchard, M.P.; Smith, B. The destination product and its impact on traveller perceptions. Tour. Manag. 2000, 21, 43-52. [CrossRef]

27. Gunn, C.; Var, T. Tourism Planning: Basic, Concepts, Case, 4th ed.; Gunn, C., Var, T., Eds.; Routledge. Taylor and Francis: London, UK, 2002.

28. Buhalis, D. Marketing the competitive destination of the future. Tour. Manag. 2000, 21, 97-116. [CrossRef]

29. Jamal, T.; Getz, D. Collaboration theory and community tourism planning. Ann. Tour. Res. 1995, 22, $186-204$. [CrossRef]

30. Gallarza, M.G.; Gil Saura, I.; García, H.C. Destination image. Ann. Tour. Res. 2002, 29, 56-78. [CrossRef]

31. Crompton, J.L. An Assessment of the Image of Mexico as a Vacation Destination and the Influence of Geographical Location Upon That Image. J. Travel Res. 1979, 17, 18-23. [CrossRef]

32. Lin, C.-H.; Morais, D.B.; Kerstetter, D.L.; Hou, J.-S. Examining the Role of Cognitive and Affective Image in Predicting Choice Across Natural, Developed, and Theme-Park Destinations. J. Travel Res. 2007, 46, 183-194. [CrossRef]

33. Tsaur, S.-H.; Yen, C.-H.; Yan, Y.-T. Destination brand identity: Scale development and validation. Asia Pac. J. Tour. Res. 2016, 21, 1-14. [CrossRef]

34. Gartner, W.C. Image Formation Process. J. Travel Tour. Mark. 1994, 2, 191-216. [CrossRef]

35. Pike, S. Destination Image Literature: 2001-2007. Acta Tur. 2007, 19, 107-125. Available online: https: //www.researchgate.net/publication/27471957_Destination_image_literature_2001_-_2007 (accessed on 30 November 2019).

36. Beerli, A.; Martín, J.D. Factors influencing destination image. Ann. Tour. Res. 2004, 31, 657-681. [CrossRef]

37. Tan, W.-K.; Wu, C.-E. An investigation of the relationships among destination familiarity, destination image and future visit intention. J. Destin. Mark. Manag. 2016, 5, 214-226. [CrossRef] 
38. Cantos, E.; Pons, R.; Tanda, J. Creación De Valor En Ciudades-Destinos Turísticos a Través De Su Imagen: Rol De La Gestión Local. Retos Turísticos 2016, 15, 153-166. Available online: http://retos.mes.edu.cu/index. php/retojs/article/view/233/203. (accessed on 23 November 2019).

39. Weidenfeld, A. Iconicity and 'flagshipness' of tourist attractions. Ann. Tour. Res. 2010, 37, 851-854. [CrossRef]

40. Grayson, K.; Martinec, R. Consumer Perceptions of Iconicity and Indexicality and Their Influence on Assessments of Authentic Market Offerings. J. Consum. Res. 2004, 31, 296-312. [CrossRef]

41. Woodside, A.G.; Cruickshank, B.F.; Dehuang, N. Stories visitors tell about Italian cities as destination icons. Tour. Manag. 2007, 28, 162-174. [CrossRef]

42. Tang, L.; Morrison, A.M.; Lehto, X.; Kline, S.; Pearce, P.L. Effectiveness criteria for icons as tourist attractions: A comparative study between the United States and China. J. Travel Tour. Mark. 2009, 26, 284-302. [CrossRef]

43. Maitland, R.; Newman, P. Developing metropolitan tourism on the fringe of central London. Int. J. Tour. Res. 2004, 6, 339-348. [CrossRef]

44. Becken, S. The role of tourist icons for sustainable tourism. J. Vacat. Mark. 2005, 11, 21-30. [CrossRef]

45. Boo, S.; Busser, J.; Baloğlu, Ş. A model of customer-based brand equity and its application to multiple destinations. Tour. Manag. 2009, 30, 219-231. [CrossRef]

46. Echtner, C.M.; Ritchie, J.B. The Measurement of Destination Image: An Empirical Assessment. J. Travel Res. 1993, 31, 3-13. [CrossRef]

47. Bregoli, I. Effects of DMO Coordination on Destination Brand Identity. J. Travel Res. 2012, 52, $212-224$. [CrossRef]

48. Fernández-Cavia, J.; Rovira, C.; Díaz-Luque, P.; Cavaller, V. Web Quality Index (WQI) for official tourist destination websites. Proposal for an assessment system. Tour. Manag. Perspect. 2014, 9, 5-13. [CrossRef]

49. L'Etang, J.; Falkheimer, J.; Lugo, J. Public relations and tourism: Critical reflections and a research agenda. Public Relat. Rev. 2007, 33, 68-76. [CrossRef]

50. Kozak, M.; Crotts, J.C.; Law, R. The impact of the perception of risk on international travellers. Int. J. Tour. Res. 2007, 9, 233-242. [CrossRef]

51. Agapito, D.; Valle, P.O.D.; Mendes, J. The Cognitive-Affective-Conative Model of Destination Image: A Confirmatory Analysis. J. Travel Tour. Mark. 2013, 30, 471-481. [CrossRef]

52. Степченкова, C.; Mills, J.E. Destination Image: A Meta-Analysis of 2000-2007 Research. J. Hosp. Mark. Manag. 2010, 19, 575-609. [CrossRef]

53. Tasci, A.D.A.; Gartner, W.C. Destination Image and Its Functional Relationships. J. Travel Res. 2007, 45, 413-425. [CrossRef]

54. Casaló, C.; Flavián, M. Observación y participación activa en comunidades virtuales comerciales: El caso del sector turismo. Rev. Española Investig. Mark. ESIC 2011, 15, 113-134.

55. Crespo, Á.H.; Gutiérrez, H.S.M.; Mogollón, J.H. Perceived influence on behavior of user-generated content on social network sites: An empirical application in the hotel sector. Rev. Española Investig. Mark. ESIC 2015, 19, 12-23. [CrossRef]

56. Roca, M. La transformación de la industria publicitaria en la era digital. Percepciones de los profesionales en Estados Unidos: Retos y oportunidades. Telos Cuad. Comun. Innovación 2014, 99, 64-74.

57. King, R.A.; Racherla, P.; Bush, V.D. What We Know and Don't Know About Online Word-of-Mouth: A Review and Synthesis of the Literature. J. Interact. Mark. 2014, 28, 167-183. [CrossRef]

58. Kim, E.; Sung, Y.; Kang, H. Brand followers' retweeting behavior on Twitter: How brand relationships influence brand electronic word-of-mouth. Comput. Hum. Behav. 2014, 37, 18-25. [CrossRef]

59. Webb, J.W.; Ireland, R.D.; Hitt, M.A.; Kistruck, G.M.; Tihanyi, L. Where is the opportunity without the customer? An integration of marketing activities, the entrepreneurship process, and institutional theory. J. Acad. Mark. Sci. 2010, 39, 537-554. [CrossRef]

60. Peters, K.; Chen, Y.; Kaplan, A.M.; Ognibeni, B.; Pauwels, K. Social Media Metrics-A Framework and Guidelines for Managing Social Media. J. Interact. Mark. 2013, 27, 281-298. [CrossRef]

61. Ren, C.; Pritchard, A.; Morgan, N. Constructing tourism research. Ann. Tour. Res. 2010, 37, 885-904. [CrossRef]

62. D'Angella, F.; Go, F.M. Tale of two cities' collaborative tourism marketing: Towards a theory of destination stakeholder assessment. Tour. Manag. 2009, 30, 429-440. [CrossRef]

63. Hankinson, G. Relational network brands: Towards a conceptual model of place brands. J. Vacat. Mark. 2004, 10, 109-121. [CrossRef] 
64. Xifra, J.; Huertas, A. Blogging PR: An exploratory analysis of public relations weblogs. Public Relat. Rev. 2008, 34, 269-275. [CrossRef]

65. Laroche, M.; Habibi, M.R.; Richard, M.-O. To be or not to be in social media: How brand loyalty is affected by social media? Int. J. Inf. Manag. 2013, 33, 76-82. [CrossRef]

66. Marine-Roig, E.; Ferrer-Rosell, B. Measuring the gap between projected and perceived destination images of Catalonia using compositional analysis. Tour. Manag. 2018, 68, 236-249. [CrossRef]

67. Zwass, V. Co-Creation: Toward a Taxonomy and an Integrated Research Perspective. Int. J. Electron. Commer. 2010, 15, 11-48. [CrossRef]

68. Sanders, E.B.-N.; Stappers, P.J. Co-creation and the new landscapes of design. CoDesign 2008, 4, 5-18. [CrossRef]

69. Fatanti, M.N.; Suyadnya, I.W. Beyond User Gaze: How Instagram Creates Tourism Destination Brand? Procedia Soc. Behav. Sci. 2015, 211, 1089-1095. [CrossRef]

70. Shuqair, S.; Cragg, P. The immediate impact of Instagram posts on changing the viewers' perceptions towards travel destinations. Asia Pac. J. Adv. Bus. Soc. Stud. 2017, 3, 1-12. [CrossRef]

71. Mariani, M.M.; Felice, M.; Mura, M. Facebook as a destination marketing tool: Evidence from Italian regional Destination Management Organizations. Tour. Manag. 2016, 54, 321-343. [CrossRef]

72. Luo, Q.; Zhong, D. Using social network analysis to explain communication characteristics of travel-related electronic word-of-mouth on social networking sites. Tour. Manag. 2015, 46, 274-282. [CrossRef]

73. Junta De Andalucía. Plan De Promoción Turística De Andalucía. 2012. Available online: http://www. juntadeandalucia.es/turismoydeporte/publicaciones/143463551.pdf (accessed on 5 September 2019).

74. Narangajavana, Y.; Fiol, L.J.C.; Tena, M.; Ángel, M.; Artola, R.M.R.; García, J.S. The influence of social media in creating expectations. An empirical study for a tourist destination. Ann. Tour. Res. 2017, 65, 60-70. [CrossRef]

75. De Bruyn, A.; Lilien, G.L. A multi-stage model of word-of-mouth influence through viral marketing. Int. J. Res. Mark. 2008, 25, 151-163. [CrossRef]

76. White, L. Facebook, friends and photos: A snapshot into social networking for generating travel ideas. In Tourism Informatics: Visual Travel Recommender Systems, Social Communities and User Interface Design; Sharda, N., Ed.; IGI Global: Hershey, PA, USA, 2010; pp. 115-129.

77. Akehurst, G. User generated content: The use of blogs for tourism organisations and tourism consumers. Serv. Bus. 2008, 3, 51-61. [CrossRef]

78. Ndou, V.; Del Vecchio, P. Empowering tourists to co-create services. In Projects and Forms of The European Digital Citizenship; Mancarella, M., Ed.; Tangram Edizioni Scientifiche: Trento, Italy, 2014; pp. 124-143.

79. Chan, J.K.L.; Quah, W.B. Start-up Factors for Small and Medium-sized Accommodation Businesses in Sabah, Malaysia: Push and Pull Factors. Asia Pac. J. Tour. Res. 2012, 17, 49-62. [CrossRef]

80. Song, H.; Bae, S.Y. Understanding the travel motivation and patterns of international students in Korea: Using the theory of travel career pattern. Asia Pac. J. Tour. Res. 2017, 23, 133-145. [CrossRef]

81. Castelló, A. La orientación empresarial hacia el cliente en la Web 2.0. Miguel Hernández Commun. J. 2010, 1, 203-239.

82. Standing, C.; Tang-Taye, J.-P.; Boyer, M. The Impact of the Internet in Travel and Tourism: A Research Review 2001-2010. J. Travel Tour. Mark. 2014, 31, 82-113. [CrossRef]

83. Agrawal, A.K.; Kaushik, A.; Rahman, Z. Co-creation of Social Value through Integration of Stakeholders. Procedia Soc. Behav. Sci. 2015, 189, 442-448. [CrossRef]

84. Gretzel, U.; Kang, M.; Lee, W. Differences in Consumer-Generated Media Adoption and Use: A Cross-National Perspective. J. Hosp. Leis. Mark. 2008, 17, 99-120. [CrossRef]

85. Marine-Roig, E.; Clavé, S.A. Perceived image specialisation in multiscalar tourism destinations. J. Destin. Mark. Manag. 2016, 5, 202-213. [CrossRef]

86. Brenner, S.N.; Cochran, P. The Stakeholder Theory of the Firm. Proc. Int. Assoc. Bus. Soc. 1991, 2, 897-933. [CrossRef]

87. Pfeffer, J.; Salancik, G.R. The External Control of Organisations; Harper and Row: New York, NY, USA, 1978.

88. Shankman, N.A. Reframing the Debate Between Agency and Stakeholder Theories of the Firm. J. Bus. Ethics 1999, 19, 319-334. [CrossRef]

89. Freeman, E. Strategic Management: A Stakeholder Approach; Cambridge University Press: Cambridge, UK, 2010. 
90. Goodpaster, K.E. Ethical Imperatives and Corporate Leadership. Ruffin 1991, 6, 89-110.

91. Timur, S.; Getz, D. A network perspective on managing stakeholders for sustainable urban tourism. Int. J. Contemp. Hosp. Manag. 2008, 20, 445-461. [CrossRef]

92. Sun, H. Destination and Event Marketing: A Case Study in The 2007 c\&d Xiamen International Marathon, Xiamen, China. Master's Thesis, University of Waterloo, Waterloo, ON, USA, 2007.

93. García, J.A.; Gómez, M.; Molina, A.; Collado, A.M. A destination-branding model: An empirical analysis based on stakeholders. Tour. Manag. 2012, 33, 646-661. [CrossRef]

94. Sheehan, L.; Ritchie, J.R.B.; Hudson, S. The Destination Promotion Triad: Understanding Asymmetric Stakeholder Interdependencies Among the City, Hotels, and DMO. J. Travel Res. 2007, 46, 64-74. [CrossRef]

95. Bitsani, E.; Kavoura, A. Connecting Oenological and gastronomical tourisms at the Wine Roads, Veneto, Italy, for the promotion and development of agrotourism. J. Vacat. Mark. 2012, 18, 301-312. [CrossRef]

96. Simpson, M.C. Community Benefit Tourism Initiatives-A conceptual oxymoron? Tour. Manag. 2008, 29, 1-18. [CrossRef]

97. Clarkson, M.B.E. A Stakeholder Framework for Analyzing and Evaluating Corporate Social Performance. Acad. Manag. Rev. 1995, 20, 92. [CrossRef]

98. Dodds, R.; Ko, S. Assessing Stakeholders' Views of Tourism Policy in Prince Edward County. Environ. Manag. Sustain. Dev. 2012, 1, 1. [CrossRef]

99. Liu, Z. Sustainable Tourism Development: A Critique. J. Sustain. Tour. 2003, 11, 459-475. [CrossRef]

100. Jamal, T.; Stronza, A.L. Collaboration theory and tourism practice in protected areas: stakeholders. Structuring and sustainability. 2009, 1, 459-475.

101. Huertas, A. Aplicación de la Web 2.0 a Los Destinos TuríSticos. Implantación y Diferencias; TURITEC: Málaga, Spain, 2008.

102. Del Vasto-Terrientes, L.; Valls, A.; Slowinski, R.; Zielniewicz, P. ELECTRE-III-H: An outranking-based decision aiding method for hierarchically structured criteria. Expert Syst. Appl. 2015, 42, 4910-4926. [CrossRef]

103. Sautter, E.T.; Leisen, B. Managing stakeholders a Tourism Planning Model. Ann. Tour. Res. 1999, 26, 312-328. [CrossRef]

104. Formica, S.; Kothari, T.H. Strategic Destination Planning: Analyzing the Future of Tourism. J. Travel Res. 2008, 46, 355-367. [CrossRef]

105. Wang, Y.; Xiang, Z. Toward a Theoretical Framework of Collaborative Destination Marketing. J. Travel Res. 2007, 46, 75-85. [CrossRef]

106. Jambrino-Maldonado, C.; De Las Heras-Pedrosa, C. Building of Corporate reputation observatory for a tourism destination. Tour. Manag. Stud. Int. Conf. Algarve 2012, 1, 66-76.

107. Saxton, G.D.; Waters, R.D. What do Stakeholders Like on Facebook? Examining Public Reactions to Nonprofit Organizations' Informational, Promotional, and Community-Building Messages. J. Public Relations Res. 2014, 26, 280-299. [CrossRef]

108. Capriotti, P. Planificación Estratégica De La Imagen Corporativa, 4th ed.; Instituto de Investigación en Relaciones Públicas: Málaga, Spain, 2013.

109. Li, M.; Cai, L.A.; Lehto, X.; Huang, J.Z. A Missing Link in Understanding Revisit Intention-The Role of Motivation and Image. J. Travel Tour. Mark. 2010, 27, 335-348. [CrossRef]

110. Chon, K.-S. The role of destination image in tourism: A review and discussion. Tour. Rev. 1990, 45, 2-9. [CrossRef]

111. Glińska, E. Sposoby Badania Wizerunku Miejsca. Samorz. Teryt. 2011, 11, 33-44.

112. Środa-Murawska, S.; Szymańska, D. Cdfmr The concentration of the creative sector firms as a potential basis for the formation of creative clusters in Poland. Bull. Geogr. Socio Econ. Ser. 2013, 20, 85-93. [CrossRef]

113. Dwivedi, A.; Merrilees, B.; Miller, D.; Herington, C. Brand, value and relationship equities and loyalty-intentions in the Australian supermarket industry. J. Retail. Consum. Serv. 2012, 19, 526-536. [CrossRef]

114. Creswell, J. Educational Research: Planning, Conducting, and Evaluating Quantitative and Qualitative Research; Pearson Education: Upper Saddle River, NJ, USA, 2007.

115. Bryman, A. Barriers to Integrating Quantitative and Qualitative Research. J. Mix. Methods Res. 2007, 1, 8-22. [CrossRef]

116. Sabharwal, N.S.; Malish, C.M. Mixed Methods Approaches and Qualitative Methodology for Higher Education Policy Research; Oxford University Press (OUP): Oxford, UK, 2018; pp. 29-50. 
117. Krippendorff, K. Content Analysis: An Introduction to its Methodology, 2nd ed.; SAGE Publications: London, UK, 2004.

118. Sánchez, J.J. Análisis De Contenido Cuantitativo De Medios; Berganza, M.R., Ruiz, J.A., Eds.; Investigar en Comunicación, McGraw Hill: Madrid, Spain, 2005.

119. Igartua, J.J. Métodos Cuantitativos De Investigación En Comunicación; Bosch: Barcelona, Spain, 2006.

120. De las Heras-Pedrosa, C.; Jambrino-Maldonado, C.; Iglesias-Sánchez, P.; Lugo-Ocando, J. Importance of Public Relations for The Reputation in a Smart Tourist Destination. A Proposal of a Sustainable Model. Revista Internacional de Relaciones Públicas 2019, 9, 117-128. [CrossRef]

121. Lotto, L.S.; Miles, M.B.; Huberman, A.M. Qualitative Data Analysis: A Sourcebook of New Methods. Educ. Eval. Policy Anal. 1986, 8, 329. [CrossRef]

122. Eisenhardt, K.M.; Graebner, M.E. Theory Building from Cases: Opportunities And Challenges. Acad. Manag. J. 2007, 50, 25-32. [CrossRef]

123. Edquist, C.; Hommen, L.; McKelvey, M. Innovation and Employment; Edward Elgar Publishing: Chalone, UK, 2001; p. 214.

124. TripAdvisor. Claves Del Verano 2018: Destinos De Playa, Mayor Presupuesto y Reservas Anticipadas. 2018. Available online: https://tripadvisor.mediaroom.com/press-releases?item=125414 (accessed on 1 October 2019).

125. Piñuel, J.L. Epistemología, metodología y técnicas del análisis de contenido. Estud. Sociolingüística 2002, 3, $1-42$.

126. Corley, K.G.; Gioia, D.A. Identity ambiguity and change in the wake of a corporate spin-off. Admin. Sci. Quart. 2013, 49, 173-208.

127. Corbin, J.; Strauss, A. Basics of Qualitative Researc: Techniques and Procedures for Developing Grounded Theory, 4th ed.; SAGE Publications: London, UK, 2015.

128. Strauss, A.; Corbin, J. Basics of Qualitative Research: Grounded Theory Procedures and Techniques, 2nd ed.; SAGE Publications: Newbury Park, CA, USA, 1990.

129. Paniagua, F.J.; Rabassa, N.; Huertas, A.; Setó, D.; Lozano, N.; Marine, E.; Míguez, M.; Ariste, S. La Comunicación de Los Destinos Turísticos y Sus Marcas a Través de Los Medios Sociales; Universitat Rovira i Virgili: Tarragona, Spain, 2016.

130. Olson, J.D.; McAllister, C.; Grinnell, L.D.; Gehrke Walters, K.; Appunn, F. Applying Constant Comparative Method with Multiple Investigators and Inter-Coder Reliability. Qual. Rep. 2016, 21, $26-42$.

131. Sarpong, D.; Razak, A.A.; Alexander, E.; Meissner, D. Organizing practices of university, industry and government that facilitate (or impede) the transition to a hybrid triple helix model of innovation. Technol. Forecast. Soc. Chang. 2017, 123, 142-152. [CrossRef]

132. Leydesdorff, L.; Etzkowitz, H. Emergence of a Triple Helix of university—industry-government relations. Sci. Public Policy 1996, 23, 2793-2896. [CrossRef]

133. Huertas, A.; Setó-Pamies, D.; Míguez-González, M.-I. Comunicación de destinos turísticos a través de los medios sociales. Prof. Inf. 2015, 24, 15-21. [CrossRef]

134. Cisco Visual Networking Index. Global Mobile Data Traffic Forecast Update, 2017-2022. 2017. Available online: https://www.cisco.com/c/en/us/solutions/collateral/service-provider/visual-networkingindex-vni/white-paper-c11-738429.pdf (accessed on 10 September 2019).

135. Teixeira, J.E. The Role of Promotional Touristic Videos in the Creation of Visit Intent to Barcelona. Int. J. Sci. Manag. Tour. 2017, 3, 463-490.

136. Hidalgo Alcazar, M.C.; Sicilia Piñero, M.; Ruiz de Maya, S. The effect of user-generated content on tourist behavior: The mediating role of destination image. Tour. Manag. Stud. 2014, 10, 158-164. Available online: https://mstudies.net/index.php/ectms/article/view/616/1131 (accessed on 30 November 2019).

137. Lo, I.S.; McKercher, B.; Lo, A.; Cheung, C.; Law, R. Tourism and online photography. Tour. Manag. 2011, 32, 725-731. [CrossRef]

138. Lalicic, L.; Huertas, A.; Moreno, A.; Gindl, S.; Jabreel, M. Do DMOs Communicate Their Emotional Brand Values? A Comparison Between Twitter and Facebook. Inf. Commun. Technol. Tour. 2017, 159-171. [CrossRef]

139. Danias, K.; Kavoura, A. The role of social media as a tool of a company's innovative communication activities. Małopolska Sch. Econ. Tarnów Res. Pap. Collect. 2013, 23, 75-83. 
140. Hay, B. Twitter Twitter-But Who is Listening? A Review of the Current and Potential Use of Twittering as a Tourism Marketing Tool; Unpublished Report; Queen Margaret University: Edinburgh, Scotland, 2011.

141. Katsoni, V.; Laloumis, D. The influence of online reviews on customers and travel agencies. Małopolska Sch. Econ. Tarnów Res. Pap. Collect. 2013, 23, 123-130.

(C) 2020 by the authors. Licensee MDPI, Basel, Switzerland. This article is an open access article distributed under the terms and conditions of the Creative Commons Attribution (CC BY) license (http://creativecommons.org/licenses/by/4.0/). 